Finance and Economics Discussion Series Divisions of Research \& Statistics and Monetary Affairs Federal Reserve Board, Washington, D.C.

\title{
The Effects of Welfare Reform and Related Policies on Single Mothers' Welfare Use and Employment in the 1990s
}

\begin{abstract}
Adam Looney
2005-45

NOTE: Staff working papers in the Finance and Economics Discussion Series (FEDS) are preliminary materials circulated to stimulate discussion and critical comment. The analysis and conclusions set forth are those of the authors and do not indicate concurrence by other members of the research staff or the Board of Governors. References in publications to the Finance and Economics Discussion Series (other than acknowledgement) should be cleared with the author(s) to protect the tentative character of these papers.
\end{abstract}




\title{
The Effects of Welfare Reform and Related Policies on Single Mothers' Welfare Use and Employment
}

\author{
Adam Looney* \\ Federal Reserve Board \\ January, 2005
}

\begin{abstract}
This paper examines how changes in tax policy, welfare programs, public health insurance, and economic conditions during the 1990s affected welfare use and employment among single mothers. Drawing on panel data from the Survey of Income and Program Participation, I give new estimates of the effects of specific policy changes and use those estimates to explain changes in economic behavior. The results suggest that Welfare Reform policies, the EITC, and improved economic conditions, in that order, were the primary determinants of changes in welfare use and employment between 1993 and 1999.
\end{abstract}

Keywords: Welfare Reform, EITC, Medicaid, Labor Supply, Single Mothers.

${ }^{*}$ E-mail: looney@frb.gov. Address: Federal Reserve Board, Washington, DC, 20551. Thanks to David Cutler, Larry Katz, Jonah Rockoff, Dan Feenberg, Dan Sichel and many others at Harvard University and the NBER for comments and useful discussions. Jon Gruber and Robin McKnight generously shared Medicaid eligibility data. Any errors are my own. This research was part of the author's Ph.D dissertation. The analysis and conclusions set forth are those of the author and do not indicate concurrence by other members of the research staff or the Board of Governors. 
In the 1990s, social insurance programs in the United States underwent a fundamental transformation that strengthened incentives for poor families to enter the work force. These changes were so dramatic that despite a plunge in welfare caseloads of 59 percent between 1993 and 1999, real public transfers to low income families actually increased.

A vast body of research suggests that policy reforms were a major contributor to the decline in welfare use and the accompanying increase in employment among single parent families. Within this literature, the effects of AFDC Waivers and Welfare Reform ${ }^{1}$ have received the most attention (CEA 1997, 1999, Bloom and Michalopoulos 2001, Schoeni and Blank 2000, Blank 2002, Grogger 2000, 2003a, 2003b, Bell 2001, Ziliak et al. 2000, Figlio and Ziliak 1999, Klerman and Danielson 2004, Grogger, Karoly, and Klerman 2002, Klerman and Haider 2004). Studies of concurrent changes to the Earned Income Tax Credit (EITC) (Ellwood 2000, Eissa and Liebman 1996) and Medicaid (Yelowitz 1995, Ham and ShoreSheppard 2003) have largely considered these programs separately, with notable exceptions being Grogger's (2003a,b) studies of Welfare Reform policies and the EITC and Meyer and Rosenbaum's (2001) examination of the labor supply of single mothers prior to 1996.

A significant challenge in this literature has been disentangling the effects of individual policies. Most policy changes over the 1990s generated similar incentives for employment, targeted the same low-income groups, were implemented at nearly the same time, and occurred during a period of economic expansion, all of which create identification issues for researchers. ${ }^{2}$ Studies examining specific policy changes in isolation may overstate the effects

\footnotetext{
${ }^{1}$ Throughout, I refer to Aid to Families with Dependent Children as AFDC and Temporary Assistance for Needy Families as TANF. Welfare Reform refers to the implementation of the Personal Responsibility and Work Opportunity Reconciliation Act of 1996, which replaced AFDC with TANF.

${ }^{2}$ For discussions of these issues see, for example, Moffit and Ver Ploeg (2000), Bell (2001), Blank (2002).
} 
of the programs they study if they do not adequately control for concurrent policy and economic changes. Because many of the policy changes have different implications for family well-being, knowing which programs had the greatest impact on behavior is important for understanding how families are fairing. For example, the expanding EITC and contracting welfare generosity both create incentives to move from welfare to work, but each has different implications for families' well-being. Sorting out these issues is important for assessing the success of past policy changes and for designing policies in the future. Finally, the most controversial changes in social policy-the imposition of time limits, sanctions, and work requirements for women with young children-and the most dramatic changes in economic behavior occurred after Welfare Reform. Since Meyer and Rosenbaum's (2001) work on the labor supply of single mothers between 1984 and 1996, few studies have provided a complete accounting of effects of multiple policy changes and addressed the question of which policies were most successful in moving families from welfare to work. An update is needed.

In this paper I provide a more comprehensive characterization of the policy environment during the 1990s and estimate how policy changes and the economy affected the employment and program participation of female household heads using panel data from the Survey of Income and Program Participation (SIPP). My strategy advances the literature in a number of ways.

First, the effects of policy changes are identified with fewer restrictions than required by previous studies. Most recent studies of social policy changes rely on comparisons between single mothers and alternate "control groups." 3 These "differences-in-differences" strategies require strong assumptions about the comparability of treatment and control groups over

\footnotetext{
${ }^{3}$ See for examples, Blank and Schoeni (2000), Eissa and Liebman (1996), or Meyer and Rosenbaum (2001).
} 
time and the exogeneity of policy changes. If treatment and controls experience differential trends or if policies are endogenously affected by the experiences of treatment groups themselves, estimates may be biased. I attempt to reduce the scope for such problems by focusing solely on single mothers. The identification strategy in this paper exploits differences in the timing of program implementation (for identifying the effects of Welfare Reform, AFDC Waivers, specific welfare policies), differences in the magnitude of changes affecting families with different numbers of children (state and federal taxes and EITCs), and discontinuous eligibility rules based on children's ages (Medicaid and CHIP, work requirements) without relying on alternative control groups.

Second, a comprehensive and detailed characterization of the policy environment including individual welfare policies, state and federal EITC expansions, and Medicaid eligibility, allows differentiation between the effects of concurrent policy changes, reduces measurement error, and facilitates an empirical strategy that relies on precisely imputing policies to similar families.

Finally, the SIPP's detailed demographic information and monthly design permits a more nuanced identification of the effects of multiple policies implemented over short periods of time and measures changes in the within-year intensity of welfare use. The SIPP provides unique demographic information such as birth dates which are required for estimating eligibility for Medicaid. Previous work suggests monthly data may be preferable to annual data when evaluating welfare use. ${ }^{4}$

To implement this strategy, I collect information on a wide variety of social programs

\footnotetext{
${ }^{4}$ See for example, Hoynes (1996), Schoeni and Blank (2000), Ziliak et al. (2000), Klerman and Danielson (2004).
} 
including specific welfare policies enacted with AFDC Waivers and TANF, state and federal income tax schedules, public health insurance program rules, as well as economic indicators such as employment rates and low-skill wages and use these policy parameters to estimate the eligibility rules, benefit levels, and employment incentives faced by a representative sample of female headed families from the SIPP. These data from the 1990-1996 panels cover the time period from late 1989 to early 2000, provide detailed family structure and demographic information, and are designed to provide accurate representations of income and social program participation at the monthly level. Using these data, I illustrate how these different policy changes restructured the opportunities available to low income families and how they altered incentives for employment.

I then estimate the effects of these policy changes on the monthly employment and program participation of female family heads. I estimate reduced form regressions that include state and year fixed effects as well as specifications including state-by-year fixed effects, state specific trends, and individual fixed effects. To facilitate comparison to estimates gleaned from annual data, I also estimate these regressions after aggregating to the annual level. The choice to use standard panel data methods is meant to avoid certain issues arising from more complex specifications with extensive lag structures (Figlio and Ziliak 1999, Ziliak et al. 2000) or stock-flow models (Klerman and Haider 2004). Retaining this specification provides more direct and obvious answers to program evaluation questions, makes the results more broadly comparable to much of the previous literature on welfare caseloads, and more closely approximates methods used in the literature on labor supply which is particularly important when analyzing employment.

I find that Welfare-Reform-related policies, the EITC, and economic activity had the 
most significant effects on welfare and work. A decomposition of the 23 percentage point drop in welfare use between 1993 and 1999 suggests that falling unemployment rates and rising low-skill wages explain 7 percent of the drop, EITC expansions 23 percent, welfare reform policies 44 percent, and declining benefit generosity 8 percent. Decomposition of the 16 percentage point increase in monthly employment of single mothers over the same period shows that 17 percent of the increase in monthly employment rates is attributable to improving economic conditions, 22 percent to EITC expansions, 26 percent to welfare reform policies, and 11 percent to declining benefit generosity. Contrary to expectations, Medicaid eligibility expansions are correlated with increased welfare use and reduced employment. Differences between estimates using monthly data and those using annualized data suggest that studies examining annual data may over estimate the effects of the economy and under estimate the effects of Welfare Reform policies.

In relation to the previous literature, these findings suggest that the EITC and Welfare Reform policies played a greater roll in moving single mothers off of welfare and into the workforce and emphasize the importance of sanction policy and work requirements relative to other Welfare Reform polices. Compared to studies that examine the same time frame (as opposed to studies that examine only pre-1996 changes), I find similar effects of the economy on welfare use and of the EITC on employment. However, the estimates in this paper suggest that the effects of the EITC on employment were mirrored in its effects on welfare use suggesting that the EITC had a more direct role in moving people off welfare and into the workforce. Furthermore, my results suggest that Welfare Reform policies were much more important both in their effects on employment and on welfare use than other studies. These differences appear to arise from differences using monthly instead of annual 
data, a more complete characterization of the policy environment, and differences in how policy variables are parameterized and identified. I argue that these differences provide a more accurate portrayal of the effects of policy changes.

This paper unfolds as follows: section 1 provides an overview of social policy changes in the 1990s, illustrates how these program changes altered the opportunities faced by low income families, and summarizes changes in welfare use and employment among single parent families over the decade. I discuss the literature on Welfare Reform and related policies in

section 2. Section 3 describes the SIPP data on single mothers used in this analysis and discusses empirical methods. The results of the analysis and a decomposition of the changes in welfare use and employment appear in section 4 . I conclude in section 5 with a discussion of the implications of these findings.

\section{Welfare Use and Welfare Policy in the 1990s}

\subsection{Changes in Social Policy}

Dissatisfied with the historical cash welfare system, which was widely perceived to discourage employment and to encourage non-traditional family structure and fertility choices, policy makers in the 1990s aimed to adjust the incentives implicit in social programs. In addition, a fundamental characteristic of policy changes over this period was the federalization of program control that gave states considerable latitude to set rules as they saw fit. AFDC was revised using "AFDC Waivers" and ultimately ended and re-invented as TANF in 1996. State and federal tax schedules were re-drawn with larger EITCs and credits for families 
with children. Public health insurance was expanded to children in poor working families.

These changes are summarized in Table $1 .{ }^{5}$ Statistics reported in the table are weighted by the actual distribution of single mothers from the SIPP to represent policies facing the average single mother. Prior to 1992, AFDC was governed largely by rules set by the federal government. Benefit levels were set by states and varied widely, but the parameters governing how benefits changed with rising earnings were effectively uniform across states. ${ }^{6}$ AFDC was modified significantly beginning in late 1992 as states received dispensation to alter federal program rules. By 1996, 27 states had enacted major AFDC Waivers. Welfare Reform (which transformed AFDC into TANF) was implemented over a much shorter time frame than AFDC Waivers; all states implemented their programs between October 1996 and February 1998. Under AFDC Waivers and TANF states altered benefit calculation rules, child support income guidelines, and child care subsidy programs, instituted more strict work requirements, and stiffened sanctions for program non-compliance. ${ }^{7}$

Changes to earnings exemptions and benefit calculation rules lowered benefit reduction rates (the effective program marginal tax rates) in many states. Benefit reduction rates fell from an average of 53.8 percent in 1990 to 37.2 percent by $1999 .{ }^{8}$ Work requirements were extended to mothers with younger children. By 1999, welfare rules exempted only 8 percent of mothers from work requirements, down from 23 percent in 1990. States imposed sanctions

\footnotetext{
${ }^{5}$ More details on these policies are provided in the appendix.

${ }^{6}$ States actually had latitude to set effective benefit reduction rates using "fill-the-gap" benefit calculations and "rateable reductions," but few states actually took advantage of these rules.

${ }^{7}$ One issue in the empirical literature has been consistently and accurately describing changes in program rules, particularly given that different sources occasionally conflict and that anecdotal evidence suggests that legislated rules sometimes differed from those actually implemented. Throughout I have attempted to use the most widely cited sources and cross-referenced those sources with other databases. For details see the appendix.

${ }^{8}$ Benefit reduction rates are measured as one minus the percentage change in total income from taking a part-time minimum wage job.
} 
ranging in severity from partial reductions in cash benefits to termination of benefits on recipients who failed to meet strengthened work requirements. The maximum cash benefit available to families in the sample falls in real terms from a peak of $\$ 478$ a month in 1990 to a low of $\$ 371$ a month in 1999, a drop of 22 percent. In addition, (and not included in the table) transitional Medicaid and child care for mothers leaving welfare rose from 12 months to 17 months for child care and to 14 months for Medicaid between 1990 and 1999. Diversion programs aimed to reduce entry into welfare and increased after 1996. TANF imposed time limits intended to curtail long term welfare use. However, generous provisions exempted many families and states could extend benefits virtually indefinitely by adjusting time limit rules or using state funds. I create an indicator variable that equals one when any state recipient may reach a binding time limit and therefore run out of eligibility. ${ }^{9}$ The fraction of women living in states where a recipient may have been terminated due to time limits rose gradually after 1996 so that in 199956 percent of mothers lived in a state where time limits could bind.

State and federal tax policy changed significantly. Between 1990 and 1996 the EITC phase-in subsidy rate was increased and the maximum credit rose substantially. In 1990, 5 states had EITCs (2 with refundable credits). In 2000, 17 states had EITCs (12 refundable). Cuts in other state and federal taxes further reduced the tax burden for low income earners. I parameterize discontinuous and changing tax rules into a comprehensive variable that

\footnotetext{
${ }^{9}$ Note that this departs from the methods advanced by Grogger and Michalopoulos (2003) that compares the experience of mothers of young versus old children before and after the implementation of time limits. Key identifying assumptions of this strategy are that Welfare Reform and AFDC Waivers have identical effects and that mothers with young versus old children respond identically to concurrent policy and economic changes. I choose not to pursue this strategy given evidence that Welfare Reform had larger effects than waivers and that welfare recipients with older children are disproportionately likely to be experiencing long welfare spells and to have poor work opportunities.
} 
measures the effect of taxes on the return to work by estimating the taxes paid and credits received for a fixed sample of working women using tax schedules in place in different states and at different points in time. I use the same sample of mothers for all of these calculations, so the only variation in this parameter arises from differences in tax schedules across states and over time. ${ }^{10}$ The average net of tax rate, which characterizes the impact of taxes on the return to entering the labor force, rose from 95 percent in 1990 to 108 percent in 1999, an increase of nearly 14 percent.

The Medicaid and CHIP programs expanded public health insurance coverage to working families. Legislation in the 1980 s required states to expand eligibility to families meeting AFDC financial eligibility requirements (but not family structure requirements), pregnant women, and, later, progressively older children in higher income families. In the late 1990s, the CHIP program further expanded eligibility to older low income children. To estimate the effects of these expansions, I simulate eligibility for children following Currie and Gruber (1996) and Cutler and Gruber (1996). I sample children of different ages in working families and estimate their Medicaid and CHIP eligibility as if they lived in different states and at different points in time. Between 1990 and 1999, the average simulated eligibility of oldest children (which characterizes eligibility for all children in the family) grew from 31 percent to 68 percent.

Finally, all of these policy changes occurred in the context of the longest recorded expansion of the US economy. Unemployment rates fell steadily and wages, while largely flat during the mid 1990s, rose significantly after 1997.

\footnotetext{
${ }^{10}$ This is similar to the "simulated policy instrument" developed in Currie and Gruber (1996) and Cutler and Gruber (1996).
} 


\subsection{The Cumulative Effect on Incentives}

To illustrate the magnitude and extent of these contemporaneous changes, I plot the budget set faced by a women with two children (aged 8 and 13) living in New York in 1990, 1994, and 1999 (see Figure 1). The graph illustrates the declining real value of welfare benefits at $\$ 0$ earnings over time because of inflation erosion while after-tax and after-transfer income rises over time at higher levels of earnings. The net result is a budget set increasingly favoring labor force participation. ${ }^{11}$

State and Federal EITC expansions are one source of the steepening and shifting out of the budget constraint over time as phase-in rates, maximum benefits, and range of coverage increase over time. In 1990, New York had no EITC and single mothers began paying taxes at $\$ 15,000$ of earnings. Between 1990 and 1999, the state EITC was expanded to $\$ 784$ and this family received a state refund up to $\$ 22,000$ in income.

In addition, the benefit reduction rate on AFDC/TANF benefits falls over time with more generous earnings exemptions. Between 1990 and 1999, the average net of benefit reduction rate and net of food stamp "wage" rose from 43 percent to 50 percent.

The large "notches" illustrate where Medicaid or CHIP eligibility ends for each child (the value of these benefits is chosen to be $\$ 1,500)$. In 1990 , children in this family lost Medicaid coverage at $\$ 14,000$ of earnings when AFDC coverage ended. In 1994, the older child's eligibility remained tied to AFDC, but Medicaid had been extended to the younger child in families earning less than $\$ 23,000$. By 1999, both children were covered to 200 percent of the federal poverty line.

\footnotetext{
${ }^{11}$ Note that these figures show only the relationship between earnings and benefits and so ignore improvements in economic conditions and the impact of work requirements, time limits, and sanction policy.
} 


\subsection{Program Participation and Employment in the 1990s}

Over the same period, employment and program participation among single mothers changed dramatically. Between 1990 and 1993, welfare participation rates among single mothers rose from 28 to 31 percent but then fell to 7 percent by $2000 .{ }^{12}$ Administrative data show that the welfare rolls fell from 5.0 million families and 14.2 million individuals in 1993 to 2.2 million families and 5.8 million individuals by $2000 .{ }^{13}$ Annual participation rates measured by the March CPS fell from 33 percent to 11 percent over the same period. ${ }^{14}$ After the recession in the early 1990s, employment rates among single mothers increased steadily. Between 1993 and 1999, monthly employment rates of single mothers rose from 54 percent to 73 percent and annual participation rates rose from 69 percent to 83 percent. $^{15}$

\section{Literature}

A large body of work links the policies implemented during the 1990s with the changes in economic behavior of poor families. Because the literature is large, this section summarizes only that work most closely related to and relevant to this paper. A more detailed discussion of specific findings is included in Section 4. For a more complete review see for example Bell (2001), Blank (2002), and Grogger, Karoly, and Klerman (2002).

Research suggests that AFDC Waivers had modest effects on welfare participation and employment prior to 1996. While results vary, these studies suggest that Waivers contributed

\footnotetext{
${ }^{12}$ Author's calculations from the SIPP.

${ }^{13}$ DHHS (2004).

${ }^{14}$ The CPS asks about AFDC or employment at any time last year, while the SIPP records monthly information.

${ }^{15}$ Author's calculations from the SIPP and March CPS.
} 
to 1 to 2 percentage point changes in welfare and work or around 15 percent of the total caseload decline before 1996, while 30-40 percent of the change can be explained by improved economic conditions (CEA 1997, 1999, Schoeni and Blank 2000, Blank 2002, Ziliak et al. 2000). Welfare Reform is generally found to have larger effects on welfare participation, employment, and income (CEA 1999, Schoeni and Blank 2000, Grogger 2003a, 2003b, Blank 2002, Ziliak et. al 2000, Figlio and Ziliak 1999).

AFDC Waiver experimental studies provided evidence that work requirements, sanctions, and financial incentives encourage work and reduce caseloads (Bloom and Michalopoulos 2001, Grogger, Karoly, and Klerman 2002). Econometric research on specific welfare policies is more limited. For example, CEA (1999) examines the effects of five separate policies and Grogger (2000, 2003a) examines time limits.

Grogger's (2003a,b) work is the most directly comparable to this work as it considers a similar time period and includes the EITC in addition to welfare policies. Grogger finds important effects of the EITC and time limits on both welfare use and employment.

In general, most disagreements in the empirical literature can be traced to a few issues. First, researchers have questioned the use of "difference-in-differences" estimators in which the effects of policy changes are identified using differences in the timing of policy changes and by comparing groups who were affected by policy changes to groups that were unaffected. The "treatment group"-usually single mothers or low-skill single mothers-are compared to "control groups" such as single women, married mothers, or better educated single mothers. These estimators can be sensitive to the choice of control group and require assumptions about how relative differences in outcomes would evolve in the absence of policy changes.

Second, coding up policy variables consistently has been a problem. Many researchers 
note that statutory rules occasionally differ from rules implemented in practice and that different sources of information on welfare rules sometimes conflict. There is not a clear solution to this problem except to cross-check sources and use the most precise information available. Further difficulties arise from translating these rules into variables amenable to regression analysis. As a result, most research on the effects of AFDC Waivers and Welfare Reform uses dummy variables that "turn on" when a Waiver or TANF is implemented and therefore estimate aggregate average effects. Few econometric studies have been able to differentiate the effects of specific Waiver or TANF policies. Given that many of these program changes had similar goals of reducing program participation and increasing employment among single parent families and were implemented at nearly the same time, estimates that ignore concurrent changes may be biased.

Finally, specification issues regarding whether to use dynamic instead of static frameworks have been controversial. These issues are addressed below in section 3 .

In addition to the work on Welfare Reform, a number of papers find that the EITC increased labor force participation (Eissa and Liebman 1996, Meyer and Rosenbaum 2001, Ellwood 2000, Hotz and Scholz 2002). More recent work incorporating post-welfare reform data corroborates these findings and suggests that the EITC was an important determinant of welfare participation and employment during Welfare Reform (Grogger 2003a, 2003b, Ellwood 2000).

Medicaid expansions are theorized to reduce AFDC/TANF and increase employment by allowing families to leave welfare without losing health insurance coverage for their children. Yelowitz (1995) finds that Medicaid expansions in the late 1980s and early 1990s increased labor supply and reduced AFDC participation. Ham and Shore-Sheppard (2003) revisit 
Yelowitz (1995) and attribute his findings to mis-specifications in his empirical strategy and omissions in his eligibility criteria calculation. Meyer and Rosenbaum (2001) find that Medicaid may have actually reduced employment among single mothers.

In attempting to make a broad assessment of recent policy changes, this paper builds on Meyer and Rosenbaum (2001). Their paper examines effects of multiple policy reforms over the 1984-1996 period and finds that the EITC had the greatest effects on the labor supply of single mothers (explaining 60 percent of the changes in employment between 1984-1996). They also find smaller but significant effects of changing welfare benefit generosity, AFDC waivers, training programs, and child care subsidies. Their estimates suggest that expansions in Medicaid eligibility had no effect or negative effects on labor supply.

\section{Data and Methods}

\subsection{Survey of Income and Program Participation}

The 1990-1993 and 1996 SIPP panels interview between 15,000 and 37,000 households at four month intervals for between 28 and 48 months, span the period from October 1989 to February 2000, and allow longitudinal analysis of families within panels. "Core" SIPP data includes monthly data on labor force participation, program participation, demographic information, family relationships, and income. From these panels I collect data from all female family heads aged 15 to 55 with own-children under age 18 . The SIPP does not separately identify certain small states and I drop observations from individuals in those states. ${ }^{16}$ All statistics and results are calculated using the appriate sample weights.

\footnotetext{
${ }^{16}$ These states are ME, VT, ND, SD, WY, and prior to $1996 \mathrm{AK}, \mathrm{MT}, \mathrm{ID}$, and IA.
} 
The average sample single mother is about 33 years old and has 1.8 children the youngest of whom is just under 7.2 years old. 37 percent are non-white (see Table 2). 38 percent have never been married and 38 percent are divorced. 25 percent have never finished high school, 37 have just a high school diploma, and 38 percent have some post-secondary education.

Table 3 provides summary statistics on the employment, income, and program participation of these families. Between 1990 and 1999, AFDC/TANF receipt fell from 28 to 7 percent and monthly employment grew from 61 to 73 percent. Total annual income grew from $\$ 21,179$ to $\$ 22,676$, while family earnings increased from $\$ 15,811$ to $\$ 18,464$ and transfers fell from $\$ 1,924$ to $\$ 1,049 .{ }^{17}$ Health insurance coverage of single mothers fell from 82 to 78 percent because of a drop in Medicaid coverage (35 to 28 percent) that was not fully offset by the increase in private health insurance ( 49 to 52 percent). The demographic features of this sample and the pattern of employment and program participation over time mirror those found in the CPS and in administrative data collected by the states.

Using monthly SIPP data has certain advantages. Hoynes (1996) notes measurement issues related to using annual data to estimate eligibility for and participation in monthly programs. Schoeni and Blank (2000) cite identification issues related to strategies that attempt to exploit the timing of Welfare Reform in annual data. Other researchers cite improvements from using monthly administrative caseload data instead of annual data (Ziliak et al. 2000, Klerman and Danielson 2004). However, administrative data often lack demographic information available in survey data that are necessary to identify eligibility for other programs and exclude observations on related outcomes like employment and income. Monthly SIPP data allows the identification of program effects using the exact timing of

\footnotetext{
${ }^{17}$ All dollar figures adjusted to $\$ 2000$ using the CPI-U.
} 
implementation and captures the within year intensity of welfare use, unlike, for example, the March CPS, which does not differentiate between individuals on AFDC for one month and those on for 12 months.

In addition, the SIPP offers a rich set of demographic and family structure information crucial to precisely attributing the program rules that apply to each family. For example, information on children's month and year of birth allows me to precisely impute birth date specific Medicaid parameters to families and to take advantage of eligibility discontinuities based on birth month.

Drawbacks include the four-month interview schedule of the SIPP which induces "seam bias" where transitions into or out of employment or program participation appear more frequently between waves than between months within an interview period. Within each SIPP panel, "seams" are uniformly distributed over the calendar year so that individual cross-sections provide unbiased measures of actual behavior. I employ a variety of techniques for dealing with seams that include controlling for seam months or keeping only interview month data and the results I present are invariant to these controls.

In addition, the 1993 SIPP panel is an outlier in terms the proportion of program recipients in the sample, a fact verified but not explained by the Census Bureau. It appears as though lower income families were simply over-sampled; Within the panel, trends in AFDC and employment parallel changes in the 1992 panel, the CPS, and administrative data. I attempt to mitigate any potential bias by including panel and wave identifiers and interactions between panel and individual characteristics. These do not significantly alter the results and, with the exception of panel effects, are omitted.

Finally, I limit the analysis to single mothers because this group is most likely to be 
affected by welfare reform policies and because the program rules and tax policies which relate to these families are well defined. The trade-off is between sample-selection bias induced by endogenous marital and fertility decisions and the gain from precisely imputing the program parameters that these women are likely to face. The literature linking welfare and tax policies to marriage, fertility, and family structure suggests the effects of policy are small. On the other hand, programs like the EITC are likely to have very different effects on women depending on their marital status and number of children.

\section{$3.2 \quad$ Strategy}

To identify the effects of these program and economic changes on labor supply and program participation, I estimate equations of the following form:

$y_{i s t}=\delta_{w r} W R_{i s t}+\delta_{\tau}\left(1-\tau_{i s t}\right)+\delta_{M} F R A C E L I G_{i s t}+\delta_{e c} E C O N_{i s t}+X_{i s t} \beta+i_{i}+t_{t}+s_{s}+\varepsilon_{i s t}$

Where $y_{i s t}$ is an outcome variable for individual $i$ in state $s$ at time $t$. $W R_{\text {ist }}$ is a vector of AFDC Waiver and Welfare Reform policies, $\left(1-\tau_{\text {ist }}\right)$ is the net of tax rate, FRACELIG $G_{\text {ist }}$ is a measure of a family's Medicaid or CHIP eligibility, and $E C O N_{i s t}$ is a vector of economic indicators for the state or MSA of residence. Welfare Reform policies include benefit levels, the net of benefit reduction rate "wage," months of transitional child care and Medicaid, indicators for sanction policy, for being exempt from work requirements based on a child's age, and for any time limit terminations, the value of available diversion payments, and 5 time categories for both AFDC Waivers and TANF. ${ }^{18}$ Tax variables include the average

\footnotetext{
${ }^{18}$ These variables are described in detail in the Appendix.
} 
net of tax rate and in certain specifications, state and federal EITC maximum benefits. $F R A C E L I G_{i s t}$ is the simulated eligibility of the families oldest child (intended to proxy for having all children Medicaid eligible) and in other specifications, that of the youngest or a measure of total family eligibility. Economic indicators include the unemployment rate at the MSA or state level, the state employment/population rate, and average wages at the 25 th percentile of the income distribution. Also included as economic controls are the level of the minimum wage, annual state child support enforcement dollars per unmarried mother, and state average child care subsidy payments (Child Care and Development Fund payments) net of "maintenance of effort" subsidies per unmarried mother. ${ }^{19}$

$X_{i s t}$ is a vector of control variables which include indicator variables for family size, marital status, panel, calendar month, level of schooling, race, and age of youngest child, a quartic in age, and the number of non-family individuals in the household. $t_{t}$ are time fixedeffects, $s_{s}$ are state fixed-effects, and in certain specifications I include person fixed-effects $\left(i_{i}\right)$. Attrition may be an issue, so I estimate specifications with indicators for each wave of sampling. Endogenous policy changes may lead to bias and there is some evidence that states applying for AFDC Waivers differed from states that did not. ${ }^{20}$ All specifications include a vector of economic variables, but I estimate alternative equations with state specific trends and with state-by-year fixed effects.

The choice to use a standard panel data framework with fixed effects instead of more complex specifications using extensive lag structures (Ziliak et al. 2000, Figlio and Ziliak

\footnotetext{
19"Maintence of Effort" (MOE) provisions of TANF required states to maintain transfer payments to lowincome families at a certain level. After TANF, states increased child care subsidies due to MOE requirements as welfare spending fell. MOE induced child care payments are therefore endogenous to welfare participation. ${ }^{20}$ Schoeni and Blank (2000).
} 
1999) or stock-flow models that examine welfare entry and exit (Klerman and Haider 2004) is motivated by a number of factors. Examining levels provides straightforward and easily interpreted answers to program evaluation questions. The fixed-effects specification facilitates direct comparisons both to previous work on welfare participation and particularly to the broader literature on labor supply. While Klerman and Haider (2004) make a compelling case for using stock-flow models to analyze caseload changes, appropriate panel data on caseloads is limited and such methods are less amenable to examining other outcomes like labor supply. In addition, the standard fixed-effects approach avoids the econometric issues that pertain to models with lagged dependent variables with fixed-effects or when errors are serially correlated.

It is helpful to point out the sources of variation that identify the effects of policy. Welfare Policies are identified primarily by differences in the timing of implementation particularly for AFDC Waiver and Welfare Reform dummy variables. The effect of work exemptions related to a child's age are identified by differences in the timing of implementation and by differences among mothers with children of different ages. The effects of time limits are identified by differences between states in the timing of implementation and the length of the time limit. The effects of transitional child care and Medicaid are identified by the timing of implementation and by differences in generosity (measured in months). The effect of sanction policy is identified differences in the timing of implementation and, in alternative specifications, differences in the severity of sanction policy as categorized by CEA (1997). The role of the economy is identified by within state (or MSA) changes over time in economic conditions. The effects of tax changes are identified by differences within states over time (for state income tax changes) and differences over time between families with different numbers 
of children (for the Federal EITC and some state EITCs). Discontinuous Medicaid eligibility rules based on a child's age and differences in eligibility of children of different ages across states and over time identify the Medicaid and CHIP variables.

Standard errors are adjusted to allow for arbitrary correlation across observations on the same individual.

\section{Results}

\subsection{AFDC/TANF}

Table 4 presents estimates of the AFDC/TANF participation equations. Column 1 provides estimates including MSA/state fixed-effects, Column 2 provides estimates with MSA/state* year fixed-effects, Column 3 includes individual fixed-effects, and Column 4 provides estimates with MSA/state fixed-effects using annualized data. In general, these estimates are consistent with expectations and are comparable to results in the previous literature. The estimates suggest that taxes, benefit reduction rates, benefit generosity, TANF implementation, and economic conditions are significant determinants of changes in the behavior of single mothers over this period.

Glancing across columns, the estimates from different specifications are similarly signed and usually of a similar magnitude. However, throughout the analysis estimates from the specifications that include MSA/state*year and individual fixed-effects (Columns 2 and 3) often appear smaller. The reduction in within-state variation over time associated with the MSA/state*year fixed-effects means that economic variables that evolve slowly over time 
and welfare policies that affect all state residents within a year are poorly identified in these specifications. Similarly, individual fixed-effects combined with the relatively short panel duration (the median duration is 32 months) reduces the identifying variation in these types of variables. Furthermore, within-person responses to policy change are necessarily short-run changes.

The coefficient on the average net of tax rate implies that changes in state and federal tax policy reduced program participation among single mothers. In all columns, this is statistically significant and economically important, suggesting that state and federal EITC expansions lowered welfare use significantly. The coefficient in Column 1 implies that increases in state and federal EITC payments between 1993 and 1999 lowered welfare use by 5.2 percentage points or 17 percent. This is substantially larger than estimates found in Grogger (2003a,b).

The coefficient on Effective AFDC/TANF Wage shows that reductions in the marginal tax rates implicit in AFDC/TANF calculations had positive but statistically insignificant effects on AFDC/TANF participation. Previous work on AFDC Waiver programs provided some evidence that more generous earnings exemptions allowed mothers to remain on welfare longer as they transitioned into the workforce and these estimates may support those findings. $^{21}$

Higher cash benefit levels increase welfare participation. The estimates in column 1 suggest that a 10 percent increase in the maximum cash benefit increases welfare participation by 4.7 percentage points. The inflation erosion of benefits therefore reduced welfare use by 6 percent between 1993 and 1999.

\footnotetext{
${ }^{21}$ Bloom and Michalopoulos (2001), Grogger, Karoly, and Klerman (2002).
} 
Welfare Reform and related policies have strong negative effects on welfare use over this time period. Work exemptions related to a child's age increase program participation as expected. Being exempt increases AFDC/TANF participation by 3.5 to 4 percentage points. Tightening exemption rules therefore contributed to falling welfare receipt.

Transitional child care and Transitional Medicaid eligibility appear to have negligible effects on welfare use. The estimate on transitional child care suggests that a 1 month increase in transitional child care reduces AFDC/TANF participation by close to 0.2 percentage points.

Sanction policy reduces AFDC/TANF participation. This is consistent with sanction policies that effectively force families off the rolls if they do not meet work participation or other requirements. These estimates suggest that sanction policy was responsible for a 9 percent drop in welfare use between 1993 and 1999.

$A F D C$ Waiver dummies seem to indicate no effects beyond that picked up by changes in benefit reduction rates and other Waiver policy changes. In equations estimated with $A F D C$ Waiver dummies and no other welfare policies, the AFDC Waiver dummies are virtually unchanged and remain statistically insignificant. However, the coefficient estimates are not statistically different from the 1 percentage point effect often found in previous work. ${ }^{22}$

The estimates on the Welfare Reform indicators suggest that Welfare Reform had a significant impact on program participation and that these effects increased over time. Between the year prior to Welfare Reform and two years after Welfare Reform, these indicators suggest a drop in TANF participation fell 6.9 percentage points (Column 1). In specifications that exclude specific policy changes and include only the Welfare Reform variables, coefficient

\footnotetext{
${ }^{22}$ Blank (2002).
} 
estimates are slightly larger. The coefficient on Welfare Reform -1 suggests that changes in welfare participation began in the 12 month period prior to welfare reform implementation. This lends credence to anecdotal evidence that welfare offices and potential welfare participants modified their behavior in anticipation of the changes. These estimates suggest that Welfare Reform (or the bundle of policies not empirically separable from the Welfare Reform indicators) reduced welfare use by 22 percent between 1993 and 1999, making it the single most important determinant of welfare use over this period.

Note that in Column 4, the estimated effect of Welfare Reform is smaller when using annual data. There are at least three potential reasons for this: attenuation bias from mis-measuring the exact timing of implementation in annual data; the effect of within-year changes in the intensity of welfare use, for example mothers experiencing shorter spells within the year, which would not be captured in annual data; and the fact that anticipatory changes in welfare use appear in the months prior to TANF implementation. This suggests that studies using annual data may underestimate the importance of Welfare Reform.

Time limits are never statistically significant and are very close to zero. This result is surprising given the large effects estimated by Grogger and Michalopoulos (2003) and Grogger (2000, 2003b). The difference stems from differences how time limits are specified. Grogger (2000, 2003b) employs specifications that interact the age of a mother's youngest child with the time limit variable. This strategy requires two crucial assumptions: First, in the absence of time limits mothers with young children would experience similar changes in the levels of welfare use to mothers with older children. However, the majority of welfare mothers are mothers with young children so that any concurrent policy changes that significantly reduce the probability of welfare use must necessarily reduce the level of welfare use among mothers 
with young children disproportionately. Second, with few exceptions, time limits were implemented at the same time as TANF so that separately identifying the effects of time limits and TANF requires a strategy that assumes that AFDC Waivers and Welfare Reform have identical effects. (Instead of including indicators and interactions for both, he includes only an indicator and interaction for "any state wide reform.") As Blank (2002) writes (of other work), requiring waivers and TANF to have identical effects is "almost surely not justified given how much more extensive were the changes involved with state TANF plans" and empirical work bears this prediction out (CEA 1999, Wallace and Blank 1999, O'Neill and Hill 2000, Schoeni and Blank 2000, this study). This restriction mechanically reduces the estimated impact of other welfare reform policies and increases the estimated impact of time limits. In fact, replicating this specification but relaxing the restriction that AFDC waivers and Welfare Reform have equal effects significantly reduces the estimated impact of time limits relative to other Welfare Reform polices.

Economic conditions influence AFDC/TANF participation. While the MSA/state*year effects and individual fixed-effects limit much of the variation identifying these effects, coefficients generally have the right sign even though they are not always significant. The probability of welfare use appears to rise with the unemployment rate and falls with the employment/population rate and 25th percentile wage. These effects appear larger when using the annual data in Column 4. It may be that monthly estimates of economic conditions are a noisier signal of the economic environment than annual averages, but specifications using monthly data where I use trailing averages of these indicators are very similar to those with current month indicators. Alternatively, it may be that economic conditions are a better predictor of any welfare participation in a given year than of the intensity of participation 
within a year. In specifications where I omit the employment/population rate and the 25th percentile wage, the coefficient on the unemployment rate is virtually unchanged and remains statistically insignificant. Given that these regressions include a minimum of MSA, month, and year fixed effects, this may not be surprising. When fewer restrictions are imposed on either time or geography, the estimated effect of the unemployment rate rises significantly. Wages at the 25th percentile appear to have significant effects in all regressions suggesting they may be a better indicator of demand for low skill labor than is the unemployment rate. The combined effects of these economic variables suggest that economic changes reduced welfare use by 5 percent between 1993 and 1999 .

Surprisingly, Medicaid expansions are correlated with increased program participation. This result is robust to a number of empirical specifications, parameterizations of eligibility criteria, and controls for various interactions of age (in years and in months), state, year, and date. Potential explanations include endogenous eligibility criteria that specifically targeted families with younger children in times of economic hardship, or differential responses to concurrent policy changes among families with younger Medicaid eligible children versus those with older children. Adequately controlling for such biases would require much more restrictive specifications that eliminate the variation that identifies other policies. However, this puzzle merits further inquiry particularly given that related literatures linking Medicaid expansions to health insurance "crowd out" and reductions in household saving often use these same empirical methods. 


\subsection{Employment}

Turning to Table 5 , these policies also affected monthly employment rates. Changes in the EITC and related tax policy increased employment. The estimates in Column 1 suggest that a 10 percentage point increase in the average net of tax rate (roughly the size of the 1994-1996 EITC expansions) increases employment by 3.6 percentage points (and 6.3 percent). This corresponds to an elasticity of employment with respect to the net of tax rate of 0.59 . These estimates are surprisingly close to other estimates of the effects of taxes and, in particular, of the EITC. For example, Meyer and Rosenbaum (2001) estimate elasticities of 0.7 using CPS data and a different empirical strategy, a different time period and different control groups. These estimates are also similar to Grogger's (2003a) estimates.

The coefficient on Effective AFDC/TANF Wage shows that falling benefit reduction rates increased employment. This is consistent with the analysis of experimental AFDC Waiver programs, which also find that increased earnings disregards encouraged work. ${ }^{23}$ Since AFDC/TANF benefit reduction rates apply only to those on welfare and the fraction of women who are both employed and on AFDC/TANF is small (about 3.7 percent of the sample is on AFDC and employed), this estimate implies an elasticity of employment with respect to the net of benefit "wage" of 1.22 . To examine the effects of changes in benefit calculations further, I re-examine the effects of these changes looking only at AFDC/TANF recipients (not shown). In this restricted case, the coefficient on the AFDC/TANF wage rises to 0.22 and is highly significant. At the mean, the implied participation elasticity is 0.78. This may help explain the rising employment rates of AFDC/TANF recipients over

\footnotetext{
${ }^{23}$ Moffitt (2002).
} 
the 1990s.

Higher cash benefit levels reduce employment. The estimates suggest that 10 percent increase in the maximum cash benefit reduces employment by 2.0 percentage points $(3.2$ percent).

Work exemptions related to a child's age reduce employment 4.6 percentage points and therefore increased employment rates among women by 1.2 percent.

Transitional child care and Transitional Medicaid eligibility yield mixed results and appear to be poorly estimated; standard errors are large, point estimates small, and in Columns 2 and 3 the coefficient on Transitional Medicaid is found to flip signs.

Sanction policy appears to have little effect or inconsistent effects on employment. Note that the estimates in Table 7 suggest that sanctions move mothers off of welfare, but do not appear to be associated with increases in employment.

AFDC Waiver dummies indicate no effects beyond that picked up by changes in BRRs and other Waiver policy changes.

The estimates on the Welfare Reform indicators suggest that Welfare Reform increased employment by 1.4 percentage points between the year before and two years after welfare reform. In Column 3, the effects of specific welfare policies are smaller but the Welfare Reform dummy variables are larger. This may be because within the 1996 panel, Welfare Reform dummies are highly collinear with other welfare policies and variation in other welfare policies from AFDC Waivers are absorbed by the individual fixed-effects. Though the components are slightly different between columns, in the aggregate welfare reform policies appear to have similar cumulative effects and increased employment by 2.4 percent.

Employment appears more sensitive to economic conditions than is welfare use. The 
probability of employment falls with the unemployment rate and rises with the employment/population rate and 25th percentile wages. Improved economic conditions increased employment among these women by close to 5 percent.

Medicaid expansions appear to reduce employment, again contrary to expectations. While Meyer and Rosenbaum (2001) find similar contradictory evidence, the cause of the relationship remains unclear.

In both Tables 4 and 5, welfare reform related policies like sanctions, work exemptions, and the Welfare Reform indicators appear to have smaller effects in the annual data. ${ }^{24}$ As discussed above, reasons for these differences include measurement error, differences in the measurement of within-year changes in welfare use and employment, and from recipients or case workers changing behavior in anticipation of policy implementation. In contrast, economic indicators appear more significant in the annual data. The differential results using monthly versus annual data are important to note as most of the work evaluating welfare reform uses annual data.

\subsection{Decomposing Changes in Employment and Welfare Use}

Table 6 uses the estimates in Column 1 of Tables 4 and 5 to decompose the changes in AFDC/TANF participation and employment into those "explained" by the various policy and economic changes. The effect of a change in each variable is measured as the change in the mean value of that variable over the time period, multiplied by its estimated coefficient. Between 1993 and 1999, monthly welfare participation fell 23.1 percentage points or 75.0

\footnotetext{
${ }^{24}$ Welfare Reform and AFDC Waiver variables are entered in the annual data as the fraction of the year that the policy is in place in keeping with the previous literature.
} 
percent while employment rose 15.8 percentage points or 27.6 percent.

Welfare Reform-related policies, the EITC, and economic activity had the most significant effects on welfare and work. Falling unemployment rates and rising low-skill wages explain 7 percent of the drop in welfare use between 1993 and 1999. EITC expansions explain 23 percent, Welfare Reform policies 44 percent, and declining benefit generosity 8 percent. Separating out the effects of specific welfare policies, sanctions and contracting work exemptions explain 14 percent and the coefficients on the Welfare Reform dummy variables suggest that 30 percent of the decline in welfare receipt is accounted for by other unspecified or not separately identifiable Welfare Reform policies.

I attribute 17 percent of the increase in monthly employment rates to improving economic conditions, 22 percent to EITC expansions, 26 percent to welfare reform policies, and 11 percent to declining benefit generosity. Contrary to expectations, Medicaid eligibility expansions are correlated with increased welfare use and reduced employment. Benefit reduction rate changes have little effect on AFDC/TANF but explain 6 percent of the increase in employment. Taken together, these estimates suggest that Welfare Reform policies, the EITC, economic activity, and declining benefit generosity, in roughly that order, were the most important determinants of changes in welfare use and employment between 1993 and 1999.

The estimated effects of the EITC on employment are similar in magnitude to those found in the literature on labor supply (Meyer and Rosenbaum 2001) and in Grogger (2003a). Similarly, the estimated effects of economic activity in this paper lie in the middle of the range of other research that suggests that between 8 and 20 percent of the decline in welfare use can be explained by economic factors (Grogger 2003a,b, O'Neill and Hill 2000, Wallace 
and Blank 1999, CEA 1999). However, the EITC is associated with a 17 percent decline welfare use in this paper versus 9 percent in Grogger (2003a) and 7 percent in Grogger (2003b). Additionally, the effect of the EITC is found to have larger effects on welfare use than on employment. These differences may stem from the more detailed characterization of state and federal tax policy particularly as it applies to mothers with 2 or more children who are more likely to be welfare recipients.

In general, the estimated effects of the EITC, economic growth, and declining benefit generosity are comparable in magnitude to the effects found in previous work. This directs attention to the differences in estimates of the effects of welfare policy. Grogger (2003a) (which examines the same time period and includes the EITC) identifies the EITC and economic activity as the most important factors affecting welfare and work between 1993 and 1999, and relegates Welfare Reform related policies (including time limits) to a lesser role. His estimates suggest that the ETIC is responsible for 34 percent of the increase in employment and 16 percent of the reduction in welfare use, economic growth explains 21 percent of employment changes and 11 percent of welfare changes, and welfare policies explain 13 percent of the increase in employment and 14 percent of the decline in welfare use.

In this paper, Welfare Reform policies explain a greater fraction of the change in welfare use (44 percent) compared with 14 percent (Grogger 2003a), 33 percent (CEA 1999), and 15 percent (Grogger 2003b). These effects are also larger in magnitude than estimates from earlier work examining pre-1996 and pre-1998 effects of AFDC Waiver effects and TANF. The estimated effects of Welfare Reform on employment are almost twice as large (25.6 percent versus 13 percent Grogger 2003a). 
Much of the difference between this work and Grogger 2003a (the most directly comparable study) stems from differences in how Welfare Reform policies are specified. Grogger imposes that AFDC Waivers and Welfare Reform have equal effects and examines separately only the effects of time limits. This has the effect of reducing the estimated magnitude of the effects of Welfare Reform post-1996. In addition, using monthly data picks up differences in the intensity of welfare use within the year and provides more precise consequently larger effects of Welfare Reform.

In addition to the aggregate differences, I allocate the effects differently among the various welfare policies. I find that work exemptions and sanction policies were the most important identifiable contributors to the decline in welfare use. Unlike Grogger (2003a, 2003b), I attribute none of the change in welfare and work to time limits. However, the TANF dummy variables remain large and significant suggesting that many policies are sufficiently collinear that they cannot be separately identified.

\section{Conclusion}

In this paper, I examine the effects of social policy changes on the program participation and employment of single mothers in the 1990s. To differentiate the effects of different policy changes, I provide a comprehensive characterization of the policy environment over the entire decade and estimate the effects of changes in policy using panel data from the SIPP. In addition to generating new estimates of the effects of specific programs like the EITC, sanction policies, and work requirements, I examine the relative importance of these different policies. A decomposition of changes in welfare use and employment highlights the 
role of Welfare Reform policies, EITC expansions, and economic growth in moving single mothers from welfare to work.

In comparison with earlier work, the results in this paper suggest that Welfare Reform played a more important role than previously believed and explains almost half of the decline in welfare use and a quarter of employment growth between 1993 and 1999. In addition, I find that among specific components of state TANF policies, the most important determinants of welfare use and employment were financial incentives, tightening work exemptions, and stricter sanction policies.

From this analysis it appears that much of the change in economic behavior among single mothers is attributable to changes that were welfare enhancing in the economic sense; policies like the EITC and financial incentives as well as growth in employment and wages. However, certain policies like sanctions and work requirements clearly reduce the opportunities available to poor families. These Welfare Reform policies reduce welfare use but are not associated with proportionate increases in employment. This suggests that for some families the transition off of welfare was not a transition into the workforce. Gauging the broader impact of these policy changes on the well-being of single-parent families requires a better understanding of how these families are fairing. 


\section{References}

[1] Bell, S. (2001) "Why Are Welfare Caseloads Falling?" Urban Institute Discussion Paper.

[2] Blank, R. (2001). "What Causes Public Assistance Caseloads to Grow?" Journal of Human Resources 36(1): 85-118.

[3] Blank, R. (2002). "Evaluating Welfare Reform in the United States." Journal of Economic Literature 40(4): 1105-1166.

[4] Bloom, D. and C. Michalopoulos (2001). How Welfare and Work Policies Affect Employment and Income: A Synthesis of Research. New York, Manpower Demonstration Research Corporation.

[5] Brookings Institution (2003). Tax Facts. www.taxpolicycenter.org.

[6] Center for Law and Social Policy and Center on Budget and Policy Priorities (1999). State Policy Documentation Project. 2003. www.spdp.org.

[7] Committee on Ways and Means (Various Years). Green Book: Background Material and data on programs within the jurisdiction of the Committee on Ways and Means. Washington, D.C., U.S. Government Printing Office.

[8] Council of Economic Advisers (1997). Explaining the Decline in Welfare Receipt, 19931996: Technical Report, Executive Office of the President of the United States.

[9] Council of Economic Advisers (1999). The Effects of Welfare Policy and the Economic Expansion on Welfare Caseloads: An Update. Technical Report, Executive Office of the President of the United States.

[10] Currie, J. and J. Gruber (1996). "Health Insurance Eligibility, Utilization of Medical Care, and Child Health." Quarterly Journal of Economics 111(2): 431-446.

[11] Cutler, D. and J. Gruber (1996). "Does Public Insurance Crowd our Private Insurance." Quarterly Journal of Economics 112(2): 391-430.

[12] Department of Health and Human Services (1997). "Setting the Baseline: A Report on State Welfare Waivers."

[13] Eissa, N. and J. Liebman (1996). "Labor Supply Response to the Earned Income Tax Credit." Quarterly Journal of Economics CXI: 615-637.

[14] Eissa, N. and H. Hoynes (1998). "The Earned Income Tax Credit and the Labor Supply of Married Couples." NBER Working Paper 6856.

[15] Ellwood, D. (2000). "The Impact of the Earned Income Tax Credit and Social Policy Reforms on Work, Marriage, and Living Arrangements." National Tax Journal 53(2): 1063-1105. 
[16] Feenberg, D. and E. Coutts (1993). "An Introduction to the TAXSIM Model." Journal of Policy Analysis and Management 12(1): 189-194.

[17] Gottschalk, P. and R. Moffitt (1994). "Welfare Dependence: Concepts, Measures, and Trends." American Economic Review 2: 327-370.

[18] Grogger, J. (2000). "Time Limits and Welfare Use." NBER Working Paper 7709.

[19] Grogger, J. (2003a). "The Effects of Time Limits and Other Policy Changes on Welfare Use, Work, and Income Among Female-Headed Families." Review of Economics and Statistics. 85(2): 394-408.

[20] Grogger, J. (2003b). "Welfare Transitions in the 1990s: The Economy, Welfare Policy, and the EITC." NBER Working Paper 9472.

[21] Grogger, J., L. Karoly, and J. Klerman. (2002) Consequences of Welfare Reform: A Research Synthesis. Santa Monica, CA: Rand, DRU-2676-DHHS.

[22] Grogger, J. and C. Michalopoulos (2003). "Welfare Dynamics under Time Limits." Journal of Political Economy, April.

[23] Gruber, J. (2002). "Medicaid." In Means-Tested Transfers in the United States. R. A. Moffitt. Chicago (Ed.), University of Chicago Press.

[24] Ham, J. and L. Shore-Sheppard (2003). "Did Expanding Medicaid Affect Welfare Participation?" NBER Working Paper 9803.

[25] Hotz, J., and J. Scholz (2002). "The Earned Income Tax Credit." In Means-Tested Transfer Programs in the United States. R. A. Moffitt (Ed.), University of Chicago Press.

[26] Hoynes, H. (1996). "Welfare Transfers in Two-Parent Families: Labor Supply and Welfare Participation Under the AFDC-UP Program," Econometrica, 64(2), 295-332.

[27] Hoynes, H. (2000). "Local Labor Markets and Welfare Spells: Do Demand Conditions Matter?" Review of Economics and Statistics 82(August): 351-368.

[28] Klerman, J. and C. Danielson (2004). "Why Did the Welfare Caseload Decline?" Rand Corporation Labor and Population Program Working Paper WR-167.

[29] Klerman, J. and S. Haider (2004). "A Stock-Flow Analysis of the Welfare Caseload: Insights from California Economic Conditions," Journal of Human Resources. 39(4).

[30] Meyer, B. and D. Rosenbaum (2001). "Welfare, the Earned Income Tax Credit, and the Labor Supply of Single Mothers." Quarterly Journal of Economics 116(August): 1063-1114.

[31] Moffitt, R. (1992). "Incentive Effects of the U.S. Welfare System: A Review." Journal of Economic Literature 30(March): 1-61. 
[32] Moffitt, R. (2002). "The Temporary Assistance for Needy Families Program." In MeansTested Transfers in the United States. R. A. Moffitt (Ed.), University of Chicago Press.

[33] Moffitt, R., and M. Ver Ploeg, (Eds.) (2000). Evaluating Welfare Reform in an Era of Transition. Washington, DC: National Academy Press.

[34] Schoeni, R. and R. Blank. (2000). "What Has Welfare Reform Accomplished? Impacts on Welfare Participation, Employment, Income, Poverty, and Family Structure." NBER Working Paper 7627.

[35] United States Department of Agriculture (Various). "Characteristics of Food Stamp Households."

[36] Urban Institute Welfare Rules Database. 2003. www.urban.org

[37] Wallace and Blank (1999) "What Goes Up Must Come Down? Explaining Recent Changes in Public Assistance Caseloads." In Economic Conditions and Welfare Reform. S. Danzinger (Ed.). Kalamazoo, MI: W.E. Upjohn Institute for Employment Research.

[38] Yelowitz, A. (1995). "The Medicaid Notch, Labor Supply, and Welfare Participation: Evidence from Eligibility Expansions." Quarterly Journal of Economics 110(4): 909-939.

[39] Ziliak, J., D. Figlio, E. Davis, and L. Connolly. (2000). "Accounting for the Decline in AFDC Caseloads: Welfare Reform or Economic Growth?" Journal of Human Resources 35(20): 570-586. 


\section{Figure 1}

\section{Budget Constraint of a Single Mother}

with Two Children (New York)

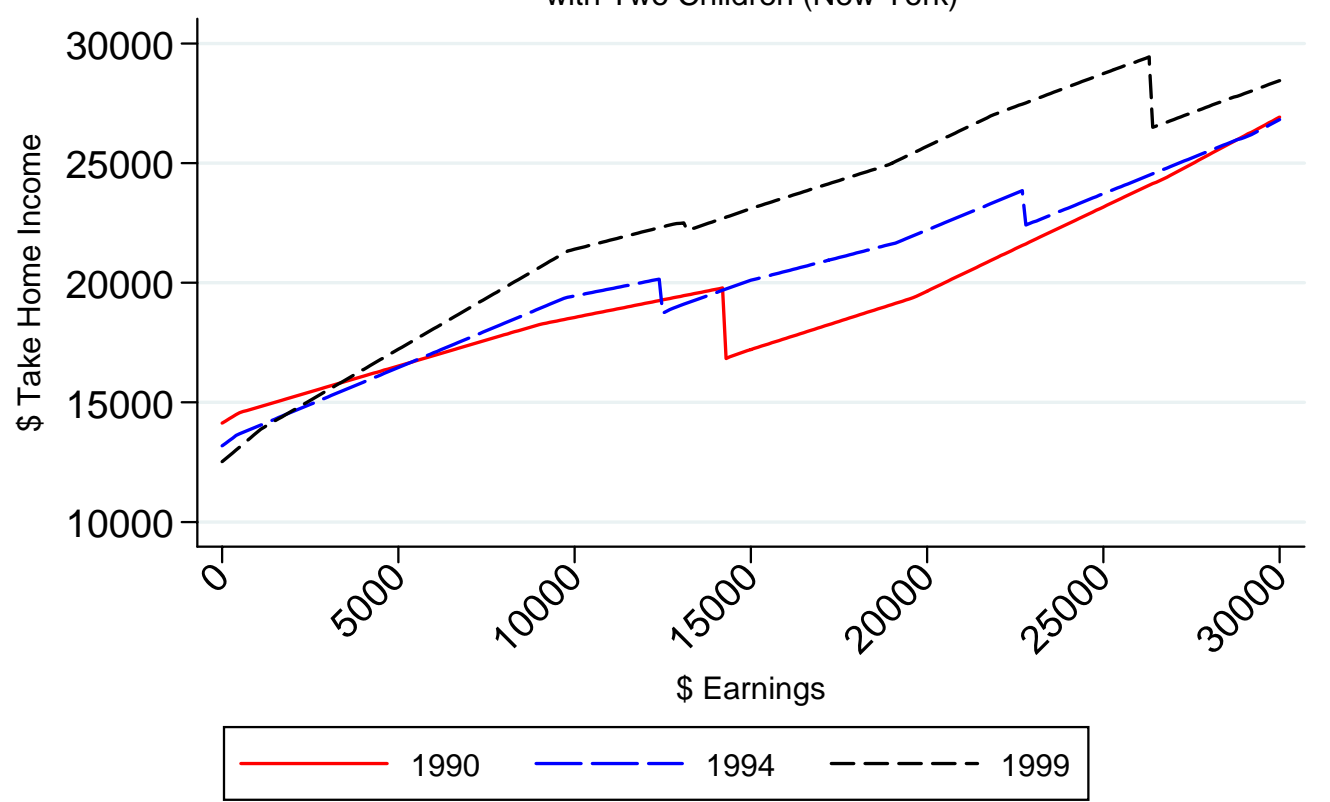

Take Home Income includes AFDC/TANF cash benefits, foodstamps, state and federal taxes and EITCs, and Medicaid. Adjusted to \$ 1999 using CPI-U.

Source:Author's calculations. 
Table 1

Changes in Welfare, Tax, and Medicaid Policy, and the Economy

\begin{tabular}{|c|c|c|c|c|c|c|c|c|c|c|}
\hline & 1990 & 1991 & 1992 & 1993 & 1994 & 1995 & 1996 & 1997 & 1998 & 1999 \\
\hline \multicolumn{11}{|l|}{ AFDC/TANF } \\
\hline \multirow[t]{2}{*}{ Any AFDC Waiver } & 0 & 0 & 0.01 & 0.22 & 0.32 & 0.36 & 0.66 & 0.81 & 0.80 & 0.80 \\
\hline & 0 & 0 & 0.11 & 0.41 & 0.47 & 0.48 & 0.47 & 0.40 & 0.40 & 0.40 \\
\hline \multirow[t]{2}{*}{ Welfare Reform } & 0 & 0 & 0 & 0 & 0 & 0 & 0.06 & 0.70 & 0.99 & 1 \\
\hline & 0 & 0 & 0 & 0 & 0 & 0 & 0.24 & 0.46 & 0.09 & 0 \\
\hline \multirow[t]{2}{*}{ Benefit Reduction Rate } & 0.53 & 0.52 & 0.52 & 0.49 & 0.47 & 0.46 & 0.44 & 0.39 & 0.38 & 0.37 \\
\hline & 0.14 & 0.14 & 0.14 & 0.14 & 0.14 & 0.15 & 0.16 & 0.14 & 0.13 & 0.13 \\
\hline \multirow[t]{2}{*}{ Sanction for non-compliance } & 0 & 0 & 0.01 & 0.03 & 0.08 & 0.15 & 0.40 & 0.77 & 1 & 1 \\
\hline & 0 & 0 & 0.09 & 0.17 & 0.28 & 0.36 & 0.49 & 0.42 & 0 & 0 \\
\hline \multirow[t]{2}{*}{ Exempt from Work b/c of Child's Age } & 0.23 & 0.24 & 0.23 & 0.23 & 0.22 & 0.21 & 0.20 & 0.13 & 0.08 & 0.08 \\
\hline & 0.42 & 0.43 & 0.42 & 0.42 & 0.41 & 0.40 & 0.40 & 0.33 & 0.27 & 0.27 \\
\hline \multirow[t]{2}{*}{ Maximum Monthly AFDC/TANF Benefit } & $\$ 478$ & 466 & 455 & 435 & 423 & 413 & 389 & 379 & 377 & 371 \\
\hline & 230 & 225 & 219 & 194 & 189 & 185 & 172 & 168 & 169 & 170 \\
\hline \multicolumn{11}{|l|}{ Taxes } \\
\hline \multirow[t]{2}{*}{ Average Net of Tax Rate } & 0.949 & 0.965 & 0.973 & 0.979 & 1.027 & 1.054 & 1.063 & 1.066 & 1.076 & 1.078 \\
\hline & 0.025 & 0.025 & 0.027 & 0.027 & 0.040 & 0.048 & 0.058 & 0.059 & 0.059 & 0.058 \\
\hline \multicolumn{11}{|l|}{ Medicaid } \\
\hline \multirow[t]{2}{*}{ Oldest Child Medicaid Eligible } & $30.6 \%$ & 32.4 & 35.2 & 38.2 & 39.1 & 40.7 & 40.8 & 43.3 & 61.9 & 68.2 \\
\hline & 19.5 & 21.3 & 22.9 & 24.0 & 23.6 & 23.6 & 22.8 & 23.3 & 21.6 & 16.7 \\
\hline \multicolumn{11}{|l|}{ The Economy } \\
\hline \multirow[t]{2}{*}{ MSA or State Unemployment Rate } & 5.66 & 6.84 & 7.60 & 7.08 & 6.21 & 5.74 & 5.36 & 4.99 & 4.55 & 4.28 \\
\hline & 1.75 & 1.88 & 2.09 & 2.04 & 1.98 & 1.92 & 1.95 & 1.94 & 1.84 & 1.63 \\
\hline \multirow{2}{*}{$\begin{array}{c}\text { State Wage at 25th Percentile } \\
\text { (Monthly) }\end{array}$} & $\$ 300$ & 299 & 295 & 295 & 287 & 288 & 287 & 292 & 303 & 311 \\
\hline & 37 & 35 & 34 & 33 & 30 & 30 & 29 & 31 & 29 & 31 \\
\hline
\end{tabular}

Sample is weighted to be representative of the population of single mothers aged 15-55. Standard deviations in italics.

Simulated Medicaid and Tax parameters are average taxes and credits and average Medicaid eligibility for a representative sample of low income working single mothers. See text for details.

See data appendix for sources.

Dollar figures are adjusted to 2000 using the CPI-U 
Table 2

Sample Demographic Summary Statistics

\begin{tabular}{|c|c|}
\hline \multirow[t]{2}{*}{ Age } & 33.3 \\
\hline & 8.6 \\
\hline \multirow[t]{2}{*}{ Number of children } & 1.8 \\
\hline & 1.0 \\
\hline \multirow[t]{2}{*}{ Non-white } & 0.37 \\
\hline & 0.48 \\
\hline \multirow[t]{2}{*}{ Never Married } & 0.38 \\
\hline & 0.48 \\
\hline \multirow[t]{2}{*}{ Divorced } & 0.38 \\
\hline & 0.49 \\
\hline \multirow[t]{2}{*}{ High School Graduate } & 0.75 \\
\hline & 0.43 \\
\hline \multirow[t]{2}{*}{ Any Post Secondary Education } & 0.38 \\
\hline & 0.49 \\
\hline \multirow[t]{2}{*}{ Live in a Metropolitan Area } & 0.78 \\
\hline & 0.41 \\
\hline \multirow[t]{2}{*}{ Age of Youngest Child } & 7.2 \\
\hline & 5.4 \\
\hline Person-Months & 373,937 \\
\hline \multicolumn{2}{|c|}{$\begin{array}{l}\text { Sample includes all female, non-married family heads aged 15-55 } \\
\text { with own-children under } 18 \text { living in their household. } \\
\text { Source: } 1990-1996 \text { SIPP Panels. }\end{array}$} \\
\hline Standard deviation in italics. & \\
\hline
\end{tabular}


Table 3 Single Mothers in the SIPP 1990-1999: Program Participation, Employment, Income, and Health Insurance

\begin{tabular}{|c|c|c|c|c|c|c|c|c|c|c|c|}
\hline & 1990 & 1991 & 1992 & 1993 & 1994 & 1995 & 1996 & 1997 & 1998 & 1999 & Average \\
\hline \multirow[t]{2}{*}{ Monthly AFDC/TANF } & 0.280 & 0.287 & 0.291 & 0.308 & 0.302 & 0.294 & 0.232 & 0.193 & 0.142 & 0.077 & 0.258 \\
\hline & 0.449 & 0.452 & 0.454 & 0.462 & 0.459 & 0.456 & 0.422 & 0.395 & 0.349 & 0.266 & 0.438 \\
\hline \multirow[t]{2}{*}{ Employed Last Month } & 0.606 & 0.593 & 0.589 & 0.573 & 0.599 & 0.601 & 0.666 & 0.693 & 0.717 & 0.731 & 0.621 \\
\hline & 0.489 & 0.491 & 0.492 & 0.495 & 0.490 & 0.490 & 0.472 & 0.461 & 0.451 & 0.444 & 0.485 \\
\hline \multirow[t]{2}{*}{ Family Earnings (Annual) } & $\$ 15,811$ & 14,959 & 14,805 & 14,219 & 14,438 & 14,268 & 15,312 & 16,180 & 17,299 & 18,464 & 15,275 \\
\hline & 18,898 & 18,409 & 18,875 & 18,160 & 17,746 & 17,559 & 18,293 & 18,713 & 19,247 & 20,542 & 18,623 \\
\hline \multirow[t]{2}{*}{ Family Income (Annual) } & $\$ 21,179$ & 20,458 & 20,171 & 19,664 & 19,626 & 19,397 & 19,988 & 20,655 & 21,565 & 22,676 & 20,370 \\
\hline & 20,019 & 19,267 & 19,651 & 18,861 & 18,561 & 18,548 & 18,943 & 19,319 & 20,055 & 21,361 & 19,406 \\
\hline \multirow[t]{2}{*}{ Health Insurance } & 0.817 & 0.829 & 0.829 & 0.824 & 0.824 & 0.806 & 0.829 & 0.780 & 0.782 & 0.776 & 0.814 \\
\hline & 0.387 & 0.377 & 0.377 & 0.381 & 0.381 & 0.395 & 0.377 & 0.414 & 0.413 & 0.417 & 0.389 \\
\hline Person-Months & 31,623 & 41,118 & 49,643 & 47,871 & 38,376 & 19,247 & 41,236 & 38,609 & 34,051 & 32,163 & 373,937 \\
\hline
\end{tabular}

Standard deviation in italics.

Sample includes monthly observations on female not-married family heads aged 15-55 with own-children under 18 .

Source: 1990-1996 panels of the SIPP. Dollar amounts adjusted to 2000 using the CPI-U. 
Table 4

The Effects of Policy Changes on Welfare Use

Average Net of Tax Rate
Effective AFDC/TANF Wage Rate

Effective AFDC/TANF Wage Rate

Maximum Cash Benefit

Exempt from Work Requirements

Months Transitional Medicaid

Months Transitional Child Care

Sanction Policy

Time Limit

Welfare Reform -1

Welfare Reform +1

Welfare Reform +2

Welfare Reform >=3

AFDC Waiver -1

AFDC Waiver +1

AFDC Waiver +2

AFDC Waiver $>=3$

Unemployment Rate

25th Percentile Wage

Employment/Population Rate

Medicaid Eligibility of Oldest Child

Fixed-effects:

Observations

R-squared
(1)

Monthly

AFDC/TANF

(2)

Monthly AFDC/TANF

$-0.527$

$(0.151)^{\star \star \star}$

0.032

(0.040)

0.285

$(0.064)^{\star \star \star}$

0.040

$(0.011)^{\star \star \star}$

0.001

(0.001)

$-0.002$

$(0.001)^{*}$

$-0.014$

$(0.005)^{\star \star \star}$

$-0.005$

$(0.010)$

$-0.019$

$(0.012)^{\star}$

$-0.046$

$(0.021)^{\star \star}$

$-0.088$

$(0.027)^{\star \star \star}$

$-0.116$

$(0.032)^{\star \star \star}$

$-0.012$

(0.009)

$-0.009$

(0.012)

$-0.012$

(0.014)

$-0.023$

(0.015)

0.351

(0.255)

$-0.050$

$(0.014)^{\star \star \star ~}$

$-0.076$

(0.049)

0.051

$(0.022)^{\star \star}$

State/MSA

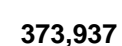

$-0.582$

$(0.159)^{\star \star \star}$

0.077

(0.086)

0.253

$(0.081)^{\star \star \star}$

0.038

$(0.011)^{\star \star \star}$

$-0.002$

(0.002)

$-0.003$

(0.002)

$-0.001$

(0.006)

$-0.008$

(0.009)

$-0.010$

(0.010)

$-0.028$

(0.019)

$-0.058$

$(0.021)^{\star \star \star}$

$-0.087$

$(0.023)^{\star \star \star}$

0.001

(0.011)

0.007

(0.017)

$-0.005$

(0.018)

$-0.034$

$(0.021)^{\star}$

$-0.021$

(0.157)

$-0.010$

(0.011)

0.009

(0.048)

0.057

$(0.025)^{\star \star}$

State/MSA*Year

373,937
(3)

Monthly AFDC/TANF

$-0.530$

$(0.175)^{\star \star \star}$

$\mathbf{0 . 0 4 8}$

(0.034)

0.011

(0.060)

0.008

(0.007)

$-0.000$

(0.006)

$-0.000$

(0.000)

$-0.000$

$(0.000)^{*}$

$-0.000$

(0.01)

$-0.022$

$(0.008)^{\star \star \star ~}$

$-0.055$

$(0.012)^{\star \star \star}$

$-0.081$

$(0.013)^{\star \star \star}$

$-0.099$

$(0.013)^{\star \star \star}$

$-0.007$

(0.006)

$-0.015$

(0.010)

$-0.008$

$-0.013$

(0.011)

$-0.024$

$(0.013)^{\star}$

0.210

(0.157)

0.569

$-0.018$

$(0.006)^{\star \star \star}$

$-0.027$

(0.018)

0.005

(0.013)

Individual

373,937
(4)

Annual AFDC/TANF

$-0.497$

$(0.143)^{\star \star \star ~}$

0.072

$(0.041)^{*}$

0.274

$(0.065)^{\star \star \star}$

0.035

$(0.012)^{\star \star \star}$

0.001

(0.001)

$-0.002$

$(0.001)^{\star \star}$

$-0.016$

$(0.006)^{\star \star \star}$

$-0.008$

$(0.007)$

$-0.049$

$(0.017)^{\star \star \star}$

Robust standard errors adjusted for clustering on the individual in parentheses.

* significant at $10 \%$; ** significant at $5 \%$; *** significant at $1 \%$

Sample includes monthly observations on single mothers aged 15-55 living with children under 18. Regressions include year fixed-

effects and indicators for marital status (separated, divorced, widowed, never married), race (black, non-white hispanic), years of schooling (6 categories), age of youngest child, number of children, relationship to household head (head of household, child of householder, no relation), month, and SIPP panel. 
Table 5

The Effects of Policy Changes on Employment

(1)

Monthly

Employment

\begin{tabular}{|c|c|c|c|c|}
\hline & Employment & Employment & Employment & Employment \\
\hline Average Net of Tax Rate & $\begin{array}{c}\mathbf{0 . 3 6 3} \\
(0.163)^{\star \star}\end{array}$ & $\begin{array}{c}0.396 \\
(0.169)^{\star \star}\end{array}$ & $\begin{array}{c}\mathbf{0 . 0 4 0} \\
(0.190)\end{array}$ & $\begin{array}{c}\mathbf{0 . 3 3 1} \\
(0.153)^{\star \star}\end{array}$ \\
\hline Effective AFDC/TANF Wage Rate & $\begin{array}{c}\mathbf{0 . 0 8 6} \\
(0.042)^{\star \star}\end{array}$ & $\begin{array}{c}\mathbf{0 . 1 5 4} \\
(0.083)^{\star}\end{array}$ & $\begin{array}{c}\mathbf{0 . 0 1 7} \\
(0.034)\end{array}$ & $\begin{array}{c}\mathbf{0 . 0 6 6} \\
(0.044)\end{array}$ \\
\hline Maximum Cash Benefit & $\begin{array}{c}-0.285 \\
(0.064)^{\star \star \star}\end{array}$ & $\begin{array}{c}-0.200 \\
(0.080)^{\star \star}\end{array}$ & $\begin{array}{c}\mathbf{0 . 0 2 5} \\
(0.061)\end{array}$ & $\begin{array}{c}-0.257 \\
(0.063)^{\star \star \star}\end{array}$ \\
\hline Exempt from Work Requirements & $\begin{array}{c}-0.046 \\
(0.011)^{\star \star \star}\end{array}$ & $\begin{array}{c}-0.042 \\
(0.011)^{\star \star \star}\end{array}$ & $\begin{array}{l}-0.000 \\
(0.004)\end{array}$ & $\begin{array}{c}-0.045 \\
(0.012)^{\star \star \star}\end{array}$ \\
\hline Months Transitional Medicaid & $\begin{array}{l}\mathbf{0 . 0 0 0} \\
(0.002)\end{array}$ & $\begin{array}{c}0.005 \\
(0.002)^{\star \star}\end{array}$ & $\begin{array}{c}-0.021 \\
(0.007)^{\star \star \star}\end{array}$ & $\begin{array}{l}-0.000 \\
(0.002)\end{array}$ \\
\hline Months Transitional Child Care & $\begin{array}{c}\mathbf{0 . 0 0 0} \\
(0.001)\end{array}$ & $\begin{array}{c}\mathbf{0 . 0 0 2} \\
(0.002)\end{array}$ & $\begin{array}{c}\mathbf{0 . 0 0 0} \\
(0.000)\end{array}$ & $\begin{array}{c}\mathbf{0 . 0 0 1} \\
(0.001)\end{array}$ \\
\hline Sanction Policy & $\begin{array}{l}\mathbf{0 . 0 0 6} \\
(0.006)\end{array}$ & $\begin{array}{c}-0.017 \\
(0.007)^{\star \star}\end{array}$ & $\begin{array}{l}-0.000 \\
(0.000)\end{array}$ & $\begin{array}{c}\mathbf{0 . 0 0 6} \\
(0.007)\end{array}$ \\
\hline Time Limit & $\begin{array}{l}-0.007 \\
(0.012)\end{array}$ & $\begin{array}{c}\mathbf{0 . 0 1 2} \\
(0.010)\end{array}$ & $\begin{array}{c}\mathbf{0 . 0 0 1} \\
(0.001)\end{array}$ & $\begin{array}{l}-0.008 \\
(0.007)\end{array}$ \\
\hline Welfare Reform -1 & $\begin{array}{c}\mathbf{0 . 0 2 8} \\
(0.012)^{\star \star}\end{array}$ & $\begin{array}{c}\mathbf{0 . 0 2 2} \\
(0.011)^{\star \star}\end{array}$ & $\begin{array}{c}\mathbf{0 . 0 3 3} \\
(0.009)^{\star \star \star}\end{array}$ & \\
\hline Welfare Reform +1 & $\begin{array}{c}\mathbf{0 . 0 3 6} \\
(0.022)^{*}\end{array}$ & $\begin{array}{c}\mathbf{0 . 0 4 6} \\
(0.020)^{\star \star}\end{array}$ & $\begin{array}{c}\mathbf{0 . 0 5 9} \\
(0.012)^{\star \star \star}\end{array}$ & $\begin{array}{c}\mathbf{0 . 0 0 9} \\
(0.019)\end{array}$ \\
\hline Welfare Reform +2 & $\begin{array}{c}\mathbf{0 . 0 4 2} \\
(0.028)\end{array}$ & $\begin{array}{c}\mathbf{0 . 0 5 9} \\
(0.022)^{\star \star \star}\end{array}$ & $\begin{array}{c}0.062 \\
(0.014)^{\star \star \star}\end{array}$ & \\
\hline Welfare Reform $>=3$ & $\begin{array}{c}\mathbf{0 . 0 3 9} \\
(0.036)\end{array}$ & $\begin{array}{c}\mathbf{0 . 0 7 8} \\
(0.024)^{\star \star \star}\end{array}$ & $\begin{array}{c}\mathbf{0 . 0 5 4} \\
(0.015)^{\star \star \star}\end{array}$ & \\
\hline AFDC Waiver -1 & $\begin{array}{c}\mathbf{0 . 0 1 0} \\
(0.009)\end{array}$ & $\begin{array}{c}\mathbf{0 . 0 0 6} \\
(0.012)\end{array}$ & $\begin{array}{l}-0.000 \\
(0.007)\end{array}$ & \\
\hline AFDC Waiver +1 & $\begin{array}{l}-0.003 \\
(0.012)\end{array}$ & $\begin{array}{c}\mathbf{0 . 0 0 2} \\
(0.017)\end{array}$ & $\begin{array}{l}-0.004 \\
(0.010)\end{array}$ & $\begin{array}{l}-0.010 \\
(0.012)\end{array}$ \\
\hline AFDC Waiver +2 & $\begin{array}{l}-0.002 \\
(0.015)\end{array}$ & $\begin{array}{c}\mathbf{0 . 0 1 1} \\
(0.020)\end{array}$ & $\begin{array}{l}-0.000 \\
(0.012)\end{array}$ & \\
\hline AFDC Waiver $>=3$ & $\begin{array}{c}\mathbf{0 . 0 1 6} \\
(0.017)\end{array}$ & $\begin{array}{c}\mathbf{0 . 0 2 7} \\
(0.024)\end{array}$ & $\begin{array}{c}\mathbf{0 . 0 0 8} \\
(0.014)\end{array}$ & \\
\hline Unemployment Rate & $\begin{array}{c}-0.764 \\
(0.268)^{\star \star \star}\end{array}$ & $\begin{array}{c}-0.320 \\
(0.170)^{\star}\end{array}$ & $\begin{array}{c}-0.346 \\
(0.167)^{\star \star}\end{array}$ & $\begin{array}{c}-0.702 \\
(0.339)^{\star \star}\end{array}$ \\
\hline 25th Percentile Wage & $\begin{array}{c}\mathbf{0 . 0 5 1} \\
(0.015)^{\star \star \star}\end{array}$ & $\begin{array}{c}\mathbf{0 . 0 3 2} \\
(0.012)^{\star \star \star}\end{array}$ & $\begin{array}{c}\mathbf{0 . 0 1 2} \\
(0.007)^{\star}\end{array}$ & $\begin{array}{c}\mathbf{0 . 1 2 1} \\
(0.048)^{\star \star}\end{array}$ \\
\hline Employment/Population Rate & $\begin{array}{c}\mathbf{0 . 1 2 0} \\
(0.051)^{\star \star}\end{array}$ & $\begin{array}{c}\mathbf{0 . 0 1 6} \\
(0.047)\end{array}$ & $\begin{array}{c}\mathbf{0 . 0 2 3} \\
(0.022)\end{array}$ & $\begin{array}{c}\mathbf{0 . 2 7 6} \\
(0.182)\end{array}$ \\
\hline Medicaid Eligibility of Oldest Child & $\begin{array}{c}-0.060 \\
(0.023)^{\star \star \star}\end{array}$ & $\begin{array}{c}-0.069 \\
(0.026)^{\star \star \star}\end{array}$ & $\begin{array}{c}\mathbf{0 . 0 0 3} \\
(0.013)\end{array}$ & $\begin{array}{c}-0.065 \\
(0.025)^{\star \star \star}\end{array}$ \\
\hline Fixed-effects: & State/MSA & State/MSA*Year & Individual & State/MSA \\
\hline $\begin{array}{l}\text { Observations } \\
\text { R-squared }\end{array}$ & $\begin{array}{c}373,937 \\
0.24\end{array}$ & $\begin{array}{c}373,937 \\
.26\end{array}$ & $\begin{array}{c}373,937 \\
0.76\end{array}$ & $\begin{array}{c}48,492 \\
0.26\end{array}$ \\
\hline
\end{tabular}

(2)

Monthly

$(0.083)^{*}$

$(0.080)^{\star *}$

$-0.042$

0.005

$0.002)^{\star *}$

(3)

Monthly

Employment

0.017

0.025

$-0.000$

(4)

Annual

0.331

$(0.153)^{\star \star}$

$-0.257$

$\mathbf{0 . 0 0 0}$

0.008

$-0.007$

0.028

0.036

0.042

0.039

(009)

.002

ses.

* significant at 10\%; ** significant at 5\%; *** significant at $1 \%$

Sample includes monthly observations on single mothers aged 15-55 living with children under 18 . Regressions include year fixed-

effects and indicators for marital status (separated, divorced, widowed, never married), race (black, non-white hispanic), years of schooling (6 categories), age of youngest child, number of children, relationship to household head (head of household, child of householder, no relation), month, and SIPP panel. 


\begin{tabular}{|c|c|c|c|c|c|c|}
\hline \multicolumn{7}{|c|}{$\begin{array}{c}\text { Table } 6 \\
\text { Decomposing Changes in AFDC Participation and Employment 1993-1999 } \\
\end{array}$} \\
\hline \multirow[b]{3}{*}{$\begin{array}{l}\text { Mean } \\
\text { Change 1993-1999 }\end{array}$} & \multicolumn{3}{|c|}{ AFDC } & \multicolumn{3}{|c|}{ Employment } \\
\hline & 1993 & & 1999 & 1993 & & 1999 \\
\hline & 0.308 & & 0.077 & 0.573 & & 0.731 \\
\hline \multirow{3}{*}{$\begin{array}{l}\text { In Levels } \\
\text { Percent Change }\end{array}$} & & 0.231 & & & 0.158 & \\
\hline & & $-75.0 \%$ & & & $27.6 \%$ & \\
\hline & Change in AFDC & $\begin{array}{l}\text { Percentage } \\
\text { Change in AFDC }\end{array}$ & $\begin{array}{c}\text { Percent of 1993- } \\
1999 \text { Change in } \\
\text { AFDC } \\
\end{array}$ & $\begin{array}{l}\text { Change in } \\
\text { Employment }\end{array}$ & $\begin{array}{c}\text { Percentage } \\
\text { Change in } \\
\text { Employment } \\
\end{array}$ & $\begin{array}{c}\text { Percent of 1993- } \\
1999 \text { Change in } \\
\text { Employment } \\
\end{array}$ \\
\hline Taxes & -0.052 & -16.9 & -22.6 & 0.036 & 6.3 & 21.5 \\
\hline BRRs & 0.004 & 1.2 & 1.6 & 0.010 & 1.8 & 6.1 \\
\hline Max Cash Benefit & -0.018 & -6.0 & -8.0 & 0.018 & 3.2 & 11.0 \\
\hline Work Exemptions & -0.006 & -2.0 & -2.7 & 0.007 & 1.2 & 4.2 \\
\hline Trans Medicaid + CC & -0.010 & -3.1 & -4.2 & 0.000 & 0.0 & 0.0 \\
\hline Sanctions & -0.027 & -8.7 & -11.6 & 0.011 & 2.0 & 6.9 \\
\hline Waiver & 0.000 & 0.0 & 0.0 & -0.012 & -2.1 & -7.2 \\
\hline Welfare Reform & -0.069 & -22.4 & -29.9 & 0.014 & 2.4 & 8.4 \\
\hline 25th Percentile Wage & -0.003 & -1.0 & -1.4 & 0.003 & 0.6 & 1.9 \\
\hline Unemployment Rate & -0.010 & -3.2 & -4.2 & 0.021 & 3.7 & 12.8 \\
\hline Employment/Population & -0.002 & -0.7 & -0.9 & 0.003 & 0.6 & 2.1 \\
\hline Medicaid Expansion & 0.015 & 5.0 & 6.6 & -0.018 & -3.1 & -10.8 \\
\hline Total: & -0.178 & -57.8 & -77.1 & 0.095 & 16.6 & 56.9 \\
\hline
\end{tabular}




\section{Data Appendix}

\subsection{AFDC Waivers and TANF}

Prior to 1992, AFDC was governed largely by rules set by the federal government. Benefit levels were set by states and varied widely, but the parameters governing how benefits changed with rising earnings were effectively uniform across states. ${ }^{1}$ The implicit marginal tax rates were high, approximating 100 percent after a few months of work. Mothers with children under a year old were exempt from any work requirements, but most states exempted mothers with children under 3 from any "work-fare" participation and required only part time participation for mothers with children under 6 . With few incentives to leave welfare for work, welfare was characterized by long dependency spells and zero earnings. ${ }^{2}$

AFDC was modified significantly beginning in late 1992 as states received dispensation to alter federal program rules. By 1996, 27 states had enacted major AFDC Waivers. Welfare Reform (which transformed AFDC into TANF) was implemented over a much shorter time frame than AFDC Waivers; all states implemented their programs between October 1996 and February 1998. Under AFDC Waivers and TANF states altered benefit calculation rules, child support income guidelines, and child care subsidy programs, instituted more strict work requirements, and stiffened sanctions for program non-compliance.

Information on specific AFDC Waiver policies is collected from the State Policy Documentation Project (2003), Council of Economic Advisors (1997), Welfare Rules Database (2003), Setting the Baseline: A Report on State Welfare Waivers (DHHS 1997), Review of Sanction Policies and Research Studies (DHHS 2003), State Implementation of Major Changes to Welfare Policies, 1992-1998, (DHHS 1999), Moffitt (2002), and Blank (2002). When imputing welfare parameters to individuals in states with different rules for different areas, I use the parameters which apply to the largest segment of the population. When data sources provide conflicting information I first attempt to verify parameters using additional sources. If differences remain unresolved I use the information from the most widely cited source. For example, appraisals of the severity of sanction policy vary occasionally by source and so I rely on DHHS (1997) as the most widely cited reliable source.

Changes over time in welfare related variables are summarized in Appendix Table 1. Statistics reported in the table are weighted by the actual distribution of single mothers from the SIPP to represent policies facing the average single mother.

Maximum AFDC/TANF Cash Benefit is simply the maximum cash benefit available to a family based on their state of residence and family size. The maximum cash benefit available to families fell in real terms from a peak of $\$ 478$ a month in 1990 to a low of $\$ 371$ a month in 1999, a drop of 22 percent. Combined AFDC/TANF and Food Stamps benefits fall only 12 percent over this time period, from $\$ 694$ to $\$ 614$.

Benefits for working families (and benefit reduction rates) are calculated as follows, subject to applicable gross income and net income tests:

$$
\text { Benefit }=\min [\text { MaxPayment }, R *(\text { PayStd }-E-\$ D-\$ C C-\% D(E-\$ D-\$ C C))]
$$

\footnotetext{
${ }^{1}$ States actually had latitude to set effective benefit reduction rates using "fill-the-gap" benefit calculations and "rateable reductions," but few states actually took advantage of these rules.

${ }^{2}$ Gottschalk and Moffit (1994).
} 
Where MaxPayment is the state specified maximum payment, $R$ is the rateable reduction, PayStd is the state specified payment standard, $E$ is earnings, $\$ D$ is the dollar amount earnings disregard, $\$ C C$ is the child care disregard, and $\% D$ is the percentage earnings disregard. Prior to welfare reform $\$ D$ and $\% D$ were set at the federal level (in the first month at $\$ 120$ and 33.3 percent). States could adjust their effective benefit reduction rate either by specifying a payment standard that exceeded the maximum payment (fill-the-gap) or by adjusting ratable reductions. I assume $\$ C C$ to be zero when calculating payments but non-zero for families with children under 6 when calculating Medicaid eligibility.

Effective AFDC/TANF Wage This is calculated to be the change in income that results from moving from zero earnings to earnings equal to 30 hours per week at the minimum wage for the first four months of employment. (This is equal to one minus the benefit reduction rate.) Earnings exemptions and benefit calculation rules changed over time, lowering benefit reduction rates (the effective program marginal tax rate) in many states. Benefit reduction rates fell from an average of 53.8 percent in 1990 to 37.2 percent by 1999 .

Sanctions States imposed sanctions on recipients who failed to meet strengthened work requirements that ranged in severity from partial reductions in cash benefits to termination of benefits. Entered as an indicator variable indicating moderate or severe sanction or a categorical variable ranging from $0-3$, where 0 is no sanction policy 3 is severe sanction policy as determined by DHHS (1997).

Exempt from Work Requirements This variable equals 1 if a woman is exempt from work requirements (or JOBS participation before TANF) based on the age (in months) of her youngest child. Work requirements were extended to mothers with younger children. Some states began requiring work for mothers 90 days after giving birth and only three states provided exemptions for mothers with children older than 12 months. By 1999, welfare rules exempted only 8 percent of mothers from work requirements, down from 23 percent in 1990.

Diversion programs aimed to reduce entry into welfare by offering a lump sum payment in exchange for a period of ineligibility or by requiring job search or training before qualifying for benefits. \$ for Diversion is the maximum dollar amount paid to TANF applicants as part of a diversion program.

Transitional Medicaid and Child Care, established by the Family Support Act of 1988 for mothers who left AFDC for work, extended child care subsidies and Medicaid eligibility for mothers leaving AFDC/TANF because of increased earnings. Months of Transitional Medicaid The number of months a mother is eligible for Medicaid. Months of Transitional $C C$ The number of months a mother is eligible for child care. Transitional Medicaid and Child Care were extended for additional months and rose from 12 months to 17 months for child care and 14 months for Medicaid between 1990 and 1999.

The AFDC Waiver and Welfare Reform indicators indicate the timing of implementation: 12 months before implementation (-1), first 12 months after implementation (1), 13-24 months after implementation (2), and $25+$ months after implementation $(>=3)$.

TANF imposed time limits that capped receipt at 60 months and the states legislated time limits between 24 and 60 months. However, generous provisions exempted many families and states could extend benefits using state funds. Many states count only months where families are in violation of program rules towards their time limit. If recipients comply with program rules there is effectively no time limit. If they do not, sanction policies in place would terminate benefits well before time limits were reached. I create an indicator variable 
Any Time Limit Terminations that equals one when any state recipient may reach a binding time limit and therefore run out of eligibility. The fraction of women living in states where a recipient may have been terminated due to time limits rose gradually after 1996 so that in 199956 percent of mothers lived in a state where TANF rules implied term limits could bind.

\subsection{State and Federal Income Taxes}

The primary source for state and federal tax information is NBER's Taxsim. Taxsim takes information on family structure, earnings, income, deductions, and other information and produces detailed calculations of state and federal tax liabilities, marginal tax rates, and tax credits. I supplement the information from Taxsim with information on rates from Hotz and Scholz (2002) and the Urban Institute/Brookings Institution Tax Policy Center (2004).

Appendix Table 2 shows that state and federal tax policy underwent significant changes. Between 1990 and 1996 the EITC phase-in subsidy rate was increased from 14 percent to 34 percent (40 percent for families with 2 or more children) and the maximum subsidy increased in real terms from $\$ 1,229$ to $\$ 2,353$ (\$3,868). In addition, expansions of the Dependent and Child Care credit and the implementation of the Child Tax Credit further reduced the tax burden for working parents. In 1990, 5 states had EITCs ( 2 with refundable credits). In 2000, 17 states had EITCs (12 refundable). Cuts in state tax rates further reduced the tax burden for low income earners. The combination of state and federal EITCs and cuts in state taxes for low income families, single mothers in certain states received refundable credits of up to $\$ .60$ for each dollar earned.

To parameterize discontinuous and changing tax rules into a comprehensive variable that measures the effect of taxes on the return to work, I sample working Single Mothers from the 1990-1996 SIPP panels. Using their earnings and family structure, I calculate taxes for this fixed sample in every state and year, adjusting earnings for inflation, assuming that they file as heads of household, claim the standard deduction, and claim as dependents all children under 19 or under 24 and full time students living in their household. I ignore property income, unemployment insurance, or similar income sources as they are quantitatively unimportant for this group and are less likely to be forecastable sources of income. I use the same sample of mothers for all of these calculations, so the only variation in this parameter arises from differences in tax schedules across states and over time. With this

method, I calculate the Average Net of Tax Rate, $\frac{\text { Earnings-Taxes }}{\text { Earnings }}$, for each state/year/number of dependents cell and the value of other tax credits like the EITC.

Between 1990 and 1999, the average EITC paid to single mothers working a minimum wage job almost tripled from $\$ 1,039$ to $\$ 2,905$ while the simulated EITC based on the actual distribution of earnings of working single mothers grew from $\$ 610$ to $\$ 1,628$. Between 1990 and 1999, average simulated state taxes also declined from $\$ 392$ to $\$ 256$. The average net of tax rate rose from 94 percent in 1990 to 108 percent in 1999, an increase of nearly 14 percent. 


\subsection{Medicaid and CHIP}

The Medicaid and CHIP programs expanded public health insurance coverage to working families significantly in the 1990s. Medicaid had historically been linked to AFDC receipt, but legislation in the 1980s required states to expand eligibility to families meeting AFDC financial eligibility requirements (but not family structure requirements), pregnant women, and, later, progressively older children in higher income families. In the late 1990s, during and after Welfare Reform implementation, Congress created the CHIP program in response to declining insurance coverage rates of low income children. The criteria and requirements for CHIP sometimes differ from Medicaid (expansions under CHIP programs had provisions to discourage crowd-out and sometimes required nominal fees) but like Medicaid the program was intended to expand health insurance to low income children. Medicaid eligibility data prior to 1996 is courtesy of Gruber and Mcknight. I supplement their data (originally from $\mathrm{MCH}$ NGA) with later MCH reports and The Green Book (various years).

Appendix Table 3 provides statistics that summarize the expansion of Medicaid and CHIP to different groups over time. The table shows that over the 1990s states expanded eligibility first based on a child's age and later to higher and higher multiples of the poverty line.

Oldest Child's Medicaid Eligibility is calculated as follows: Medicaid and Chip eligibility parameters (expressed as a percent of the federal poverty line) are matched to children based on their birth date, state of residence, and the date (year and month). Following Currie and Gruber (1996) and Cutler and Gruber (1996), I sample 300 children from each age group (0-18), from the entire SIPP sample of working female headed families and calculate their AFDC/TANF eligibility (based on state AFDC/TANF parameters and assigning child care expenses to families with children under 6), and their Medicaid or CHIP eligibility based on their income, family size, the federal poverty level, and the Medicaid or CHIP eligibility criteria. For each state-birth date-date cell, I calculate the average eligibility of children and assign the average eligibility for that cell to children in the actual state/birth date/date group. I focus on a mother's oldest child because eligibility of oldest children characterizes eligibility for all children in the family. Between 1990 and 1999, the average simulated eligibility grew from 31 percent to 68 percent.

\subsection{Economic Environment}

All of these policy changes occurred in the context of the longest recorded expansion of the US economy. Unemployment Rate is the state or MSA level seasonally adjusted unemployment rate from the BLS (2003). The 25th Percentile Wage is the wage at the 25th percentile of the earnings distribution of all workers calculated from the CPS Merged Outgoing Rotation Group. Employment/Population Rate is calculated from the CPS Merged Outgoing Rotation Group at the state level.

Appendix Table 4 shows that the recession of the early 1990s gave way to a long economic improvement. Unemployment rates fell steadily and wages, while largely flat during the mid 1990s, rose significantly after 1997. In addition, the real value of the minimum wage rose 11 percent between 1990 and 1999. 
Appendix Table 1

AFDC Waiver and TANF Policies

\begin{tabular}{|c|c|c|c|c|c|c|c|c|c|c|}
\hline & 1990 & 1991 & 1992 & 1993 & 1994 & 1995 & 1996 & 1997 & 1998 & 1999 \\
\hline \multirow[t]{2}{*}{ Any AFDC Waiver } & 0 & 0 & 0.01 & 0.22 & 0.32 & 0.36 & 0.66 & 0.81 & 0.80 & 0.80 \\
\hline & 0 & 0 & 0.11 & 0.41 & 0.47 & 0.48 & 0.47 & 0.40 & 0.40 & 0.40 \\
\hline \multirow{2}{*}{ Welfare Reform } & 0 & 0 & 0 & 0 & 0 & 0 & 0.06 & 0.70 & 0.99 & 1 \\
\hline & 0 & 0 & 0 & 0 & 0 & 0 & 0.24 & 0.46 & 0.09 & 0 \\
\hline \multirow{2}{*}{ Benefit Reduction Rate } & 0.53 & 0.52 & 0.52 & 0.49 & 0.47 & 0.46 & 0.44 & 0.39 & 0.38 & 0.37 \\
\hline & 0.14 & 0.14 & 0.14 & 0.14 & 0.14 & 0.15 & 0.16 & 0.14 & 0.13 & 0.13 \\
\hline \multirow{2}{*}{ Sanction for non-compliance } & 0 & 0 & 0.01 & 0.03 & 0.08 & 0.15 & 0.40 & 0.77 & 1 & 1 \\
\hline & 0 & 0 & 0.09 & 0.17 & 0.28 & 0.36 & 0.49 & 0.42 & 0 & 0 \\
\hline \multirow{2}{*}{$\begin{array}{l}\text { Exempt from Work b/c of Child's } \\
\text { Age }\end{array}$} & 0.23 & 0.24 & 0.23 & 0.23 & 0.22 & 0.21 & 0.20 & 0.13 & 0.08 & 0.08 \\
\hline & 0.42 & 0.43 & 0.42 & 0.42 & 0.41 & 0.40 & 0.40 & 0.33 & 0.27 & 0.27 \\
\hline \multirow{2}{*}{ Any Time Limit Terminations } & 0 & 0 & 0 & 0 & 0 & 0 & 0.01 & 0.16 & 0.41 & 0.56 \\
\hline & 0 & 0 & 0 & 0 & 0 & 0 & 0.07 & 0.37 & 0.49 & 0.50 \\
\hline \multirow{2}{*}{ Months of Transitional Medicaid } & 12.0 & 12.0 & 12.1 & 12.4 & 12.4 & 12.4 & 13.1 & 14.0 & 14.0 & 14.0 \\
\hline & 0.0 & 0.0 & 1.0 & 2.1 & 2.1 & 2.2 & 3.4 & 4.0 & 4.0 & 4.0 \\
\hline \multirow{2}{*}{$\begin{array}{l}\text { Months of Transitional Child } \\
\text { Care }\end{array}$} & 12.0 & 12.0 & 12.0 & 12.0 & 12.6 & 12.6 & 13.8 & 17.3 & 17.8 & 17.6 \\
\hline & 0.0 & 0.0 & 0.0 & 0.2 & 2.6 & 2.6 & 4.1 & 6.0 & 6.2 & 6.2 \\
\hline \multirow{2}{*}{ \$ Diversion Payments } & $\$ 0$ & 0 & 0 & 0 & 0 & 0 & 39 & 369 & 416 & 412 \\
\hline & 0 & 0 & 0 & 0 & 0 & 0 & 236 & 719 & 745 & 742 \\
\hline \multirow{2}{*}{$\begin{array}{l}\text { Maximum Monthly AFDC/TANF } \\
\text { Benefit }\end{array}$} & $\$ 478$ & 466 & 455 & 435 & 423 & 413 & 389 & 379 & 377 & 371 \\
\hline & 230 & 225 & 219 & 194 & 189 & 185 & 172 & 168 & 169 & 170 \\
\hline Max. Monthly Foodstamp \& & $\$ 694$ & 696 & 690 & 672 & 656 & 652 & 628 & 620 & 617 & 614 \\
\hline AFDC/TANF & 215 & 216 & 216 & 199 & 195 & 194 & 183 & 180 & 179 & 180 \\
\hline
\end{tabular}

Sample is weighted to be representative of the population of single mothers aged 15-55. Standard deviations in italics.

AFDC Waiver and Welfare Reform variables indicate fraction of the population living in states with AFDC Waivers or Welfare reform in effect.

Sources: DHHS (1997), CEA (1997), Greenbook (various years), USDA (various years), Urban Institute WRD and State Database (as of 2003), SPDP (2003).

Benefits are monthly values adjusted to 2000 using the CPI-U. 
Appendix Table 2

State and Federal Taxes

\begin{tabular}{|c|c|c|c|c|c|c|c|c|c|c|}
\hline & 1990 & 1991 & 1992 & 1993 & 1994 & 1995 & 1996 & 1997 & 1998 & 1999 \\
\hline \multicolumn{11}{|l|}{ Federal EITC Parameters } \\
\hline Maximum Credit (1 Child) (\$/yr) & $\$ 1,229$ & 1,476 & 1,594 & 1,678 & 2,321 & 2,325 & 2,314 & 2,324 & 2,352 & 2,344 \\
\hline Maximum Credit (2+ Children) (\$/yr) & $\$ 1,229$ & 1,530 & 1,666 & 1,768 & 2,879 & 3,453 & 3,824 & 3,845 & 3,890 & 3,868 \\
\hline Phase-in rate (1 Child) & 14.0 & 16.7 & 17.6 & 18.5 & 23.6 & 34.0 & 34.0 & 34.0 & 34.0 & 34.0 \\
\hline Phase-in rate $(2+$ Children $)$ & 14.0 & 17.3 & 18.4 & 19.5 & 30.0 & 36.0 & 40.0 & 40.0 & 40.0 & 40.0 \\
\hline \multicolumn{11}{|l|}{ Simulated Tax Parameters: } \\
\hline \multirow[t]{2}{*}{ Average EITC at the Minimum Wage } & $\$ 1,039$ & 1,348 & 1,424 & 1,426 & 2,141 & 2,550 & 2,678 & 2,828 & 2,924 & 2,905 \\
\hline & 107 & 99 & 115 & 107 & 229 & 212 & 345 & 461 & 524 & 508 \\
\hline \multirow[t]{2}{*}{ Average EITC } & $\$ 610$ & 748 & 827 & 877 & 1286 & 1493 & 1586 & 1606 & 1639 & 1628 \\
\hline & 31 & 38 & 42 & 47 & 162 & 280 & 394 & 397 & 402 & 398 \\
\hline \multirow[t]{2}{*}{ State Taxes } & $\$ 392$ & 397 & 400 & 399 & 375 & 350 & 317 & 301 & 269 & 259 \\
\hline & 220 & 224 & 229 & 226 & 224 & 220 & 235 & 237 & 237 & 235 \\
\hline \multirow[t]{2}{*}{ Average Net of Tax Rate } & 0.949 & 0.965 & 0.973 & 0.979 & 1.027 & 1.054 & 1.063 & 1.066 & 1.076 & 1.078 \\
\hline & 0.025 & 0.025 & 0.027 & 0.027 & 0.040 & 0.048 & 0.058 & 0.059 & 0.059 & 0.058 \\
\hline
\end{tabular}

Sample is weighted to be representative of the population of single mothers aged 15-55. Standard deviations in italics.

Sources: NBER Taxsim, Urban Institute \& Brookings Institution Tax Policy Center, Hotz and Scholz (2002).

Simulated parameters are average taxes and credits for a sample of low income, working single mothers. See text for details.

Dollar figures are adjusted to 2000 using the CPI-U 
Appendix Table 3

Medicaid Eligibility

\begin{tabular}{|c|c|c|c|c|c|c|c|c|c|c|}
\hline & 1990 & 1991 & 1992 & 1993 & 1994 & 1995 & 1996 & 1997 & 1998 & 1999 \\
\hline \multicolumn{11}{|c|}{ Median State Medicaid Eligibility Threshold (\% of Federal Poverty Line) } \\
\hline Infants & 100 & 133 & 133 & 133 & 133 & 133 & 185 & 185 & 185 & 200 \\
\hline 6 Year olds & 0 & 0 & 100 & 100 & 100 & 100 & 100 & 100 & 150 & 200 \\
\hline 12 Year olds & 0 & 0 & 0 & 0 & 0 & 0 & 100 & 100 & 150 & 200 \\
\hline 15 Year olds & 0 & 0 & 0 & 0 & 0 & 0 & 0 & 0 & 100 & 200 \\
\hline \multicolumn{11}{|l|}{ Simulated Eligibility } \\
\hline Fraction of Oldest Children & $30.6 \%$ & 32.4 & 35.2 & 38.2 & 39.1 & 40.7 & 40.8 & 43.3 & 61.9 & 68.2 \\
\hline Medicaid Eligible & 19.5 & 21.3 & 22.9 & 24.0 & 23.6 & 23.6 & 22.8 & 23.3 & 21.6 & 16.7 \\
\hline
\end{tabular}

Sample is weighted to be representative of the population of single mothers aged 15-55. Standard deviations in italics.

Sources: Medicaid from Gruber and Yellowitz (1999), NGA's MCH Reports.

Medicaid thresholds are as of January each year. 
Appendix Table 4

The Economic Environment

\begin{tabular}{|c|c|c|c|c|c|c|c|c|c|c|}
\hline & 1990 & 1991 & 1992 & 1993 & 1994 & 1995 & 1996 & 1997 & 1998 & 1999 \\
\hline MSA or State & 5.66 & 6.84 & 7.60 & 7.08 & 6.21 & 5.74 & 5.36 & 4.99 & 4.55 & 4.28 \\
\hline Unemployment Rate & 1.75 & 1.88 & 2.09 & 2.04 & 1.98 & 1.92 & 1.95 & 1.94 & 1.84 & 1.63 \\
\hline State Employment I & 75.5 & 74.4 & 74.1 & 74.4 & 75.1 & 75.5 & 76.2 & 76.8 & 77.1 & 77.2 \\
\hline Population & 3.9 & 4.0 & 4.1 & 4.1 & 4.3 & 4.3 & 4.2 & 4.0 & 3.7 & 3.6 \\
\hline State Wage at 25th & $\$ 300$ & 299 & 295 & 295 & 287 & 288 & 287 & 292 & 303 & 311 \\
\hline Percentile & 37 & 35 & 34 & 33 & 30 & 30 & 29 & 31 & 29 & 31 \\
\hline \multirow{2}{*}{ Minimum Wage } & $\$ 4.8$ & 5.2 & 5.2 & 5.0 & 4.9 & 4.8 & 4.8 & 5.2 & 5.4 & 5.3 \\
\hline & 0.2 & 0.3 & 0.2 & 0.2 & 0.2 & 0.2 & 0.3 & 0.2 & 0.2 & 0.3 \\
\hline
\end{tabular}

Sample is weighted to be representative of the population of single mothers aged 15-55. Standard deviations in italics.

Sources: Unemployment rate from BLS; Employment/Population rate and wages calculated using the CPS MORG; minimum wage data from BLS.

25th percentile wage measured using all employed individuals.

All dollar amounts adjusted to 2000 using the CPI-U 